\title{
Okul Öncesi Dönem Çocukların Matematiksel Kavramlara İlişkin Hatalarının Öğretmen Görüşleri Açısından İncelenmesi*
}

\author{
Preschool Children's Errors in Mathematical Concepts, in Terms of Teachers' Views \\ Ömer Şahin ${ }^{\mathrm{a}, * *}$, Halil İbrahim Korkmaz ${ }^{\mathrm{b}}$ \\ ${ }^{\text {a }}$ Dr. Öğr. Üyesi, Amasya Üniversitesi, Eğitim Fakültesi, Matematik ve Fen Bilimleri Eğitimi Bölümü, 05100, Amasya/Türkiye. \\ ORCID: 0000-0001-7449-3627

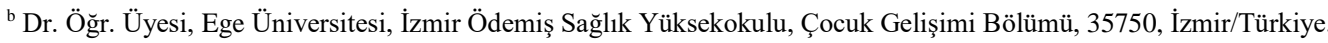 \\ ORCID: 0000-0002-0424-6150
}

\section{MAKALE BİLGİİ \\ Makale Geçmişi \\ Başvuru tarihi: 06 Şubat 2019 \\ Düzeltme tarihi: 15 Ağustos 2019 \\ Kabul tarihi: 02 Eylül 2019}

Anahtar Kelimeler:

Hata

Kavram Yanılgis1

Matematiksel Kavramlar

Okul Öncesi Matematik Eğitim

\section{ARTICLE INFO}

Article history:

Received 06 February 2019

Received in revised form 15 August 2019

Accepted 02 September 2019

\section{Keywords:}

Error

Misconception

Mathematical Concepts

Preschool Mathematics Education
ÖZ

$\mathrm{Bu}$ araştırmada okul öncesi dönemdeki çocukların sıklıkla hata yaptıkları matematiksel kavramlar öğretmen görüşleri açısından incelenmiştir. Araştırmaya 16 okul öncesi öğretmeni katılmıştır. Çocuklar tarafindan sıklıkla hata yapılan kavramların, hata türlerinin, hata nedenlerinin ve öğretmenlerin hataları giderme stratejilerinin belirlenmesi amacıyla yarı-yapılandırılmış görüşmeler gerçekleştirilmiştir. Araştırmanın sonucunda çocukların en çok "çember", "kenar", "geniş-dar", "para", "sağ-sol", "10-20 arası sayılar" "derin-sığ" ve "dün-bugün-yarın" kavramlarına ilişkin hata yaptıkları, kavramlara ilişkin en çok "kavram karmaşası" yaşadıkları, öğretmenlerin en çok çocuktan kaynaklı nedenleri öne sürdüğü, son olarak öğretmenlerin sayı kavramları dıșında șekil, boyut, miktar, yer-yön, zıtlık ve zaman kavramlarına ilișkin hataların giderilmesine yönelik uygun stratejiler kullandıkları görülmüştür. Bu araştırmaların sonuçlarında okul öncesi öğretmen yetiştirme, sunulan eğitim hizmetini geliştirme ve araştırma açısından hataları ortaya çıkarma ve gidermeye yönelik özel uygulamalar-araçlar geliştirilebilir.

\section{A B S T R A C T}

The aim of this study was to investigate preschool children's common errors in mathematical concepts, in terms of teachers' views. Sixteen preschool teachers participated this study. Teachers were interviewed to determine children's common mistakes on mathematical concepts, types, sources and causes of mistakes and strategies to fix them. It was seen that, children mostly make mistakes regarding the concepts of "circle", "edge", "narrow-wide", "money", "right-left", "numbers from 10 to 20", "shallow-deep" and "yesterday-to day-tomorrow". And, they mostly have concept confusion. Teacher mostly consider factors arising from children, as causes of errors. Last, strategies that offered by teachers to fix children's errors in concepts of "shape", "size" "quantity", "directions", "antonyms" and "time" were mostly appropriate, but not for "numbers". Some special implementations or instruments intended to develop teacher training programs, inservice facilities and studies to find out and fix children's errors, should be developed.

\section{Giriş}

Çağımızda yaşanan gelişmeler ve modern toplumların ihtiyaçları matematik öğrenme alanını çok daha fazla önemsenen ve popüler bir alan haline getirmiştir (Bishop,
Hart, Lerman ve Nunes, 1993; Sarama ve Clements, 2009). Okul öncesi dönemden en üst öğrenme kademelerine kadar olan eğitimsel süreçlerde, çeşitli gelişim ve öğrenme alanlarına yönelik olarak birçok kavramın çocuklar tarafından kazanılmış olması beklenir. $\mathrm{Bu}$ öğrenme

* Bu çalışma 9-11 kasım 2017 tarihleri arasında Ankara'da düzenlenen "International Congress On Political, Economic and Social Studies (ICPESS 2017)“ isimli konferansta, "Okul Öncesi Dönem Çocukların Matematiksel Kavramları Kazanma Sürecinde Yaşadı̆̆ Zorluklar" başl1klı sözlü bildiri olarak sunulmuştur.

** Sorumlu yazar/Corresponding author

e-posta: mersahin60@gmail.com 
alanlarından bir tanesi de matematik öğrenme alanıdır (NCTM [National Council of Teachers of Mathematics], 2006; MEB [Milli Eğitim Bakanlığ1], 2013). Küçük çocukların matematik öğrenimi konusunda doğal bir eğilimleri vardır. Çocuklar öğrenme ve araştırma merakları, arzuları ve denemekten asla bıkmayan yapıları sayesinde matematiksel kavramlara ilişkin düşüncelerinin temellerini oluştururlar. Böylece kendi deneyimleri sayesinde matematiğe ve matematiksel kavramlara yönelik anlayışlarını geliştirmiş olurlar (Copley, 2000; Kandır ve Orçan, 2010). Erken çocukluk döneminde geliştirilen matematiksel anlayışlar ve oluşturulan temeller, çocukların ileriki dönemlerde matematik öğrenme alanındaki başarısını önemli derecede etkilemektedir (Classens, Duncan ve Engel, 2009; Nguyen, vd., 2016; Watts, Duncan, Siegler ve Davis-Kean, 2014).

Matematiksel anlayış ve beceriler akademik başarının yanında çocukların günlük yaşam deneyimleri dahi etkileyen ve şekillendiren unsurlardır. Çocukların erken dönemde sahip olacakları matematiksel anlayış ve beceriler onların problemlerini çözmelerinde, karar verme süreçlerinde, teknolojiyi kullanmalarında, dünyayı anlamalarında, kendi düzeylerinde zaman ve harçlık gibi çeşitli imkanları verimli kullanabilmelerinde etkili olmaktadır. Böylelikle sahip olunan matematiksel anlayışlar ve beceriler çocukların günlük yaşamını kolaylaştırmış olur (OME [Ontario Ministry of Education], 2007). Bu açıdan erken çocukluk döneminde matematik eğitimi ihmale gelmeyecek kadar önemli bir konudur (Sperry-Smith, 2006).

Küçük çocukların matematikle ilgili bilgi sahibi olamayacağı, matematiksel anlayış geliştiremeyeceği şeklindeki yanlış inanışın (Sperry-Smith, 2006) aksine matematik günlük yaşamımızın içinde olduğundan çocuklar matematiği adeta yaşamaktadırlar. Oyunları, dünyayı anlama çabaları ve karşılaştıkları uyarıcılara verdikleri tepkiler sayesinde matematiği keşfetmektedirler. Günümüz toplumlarının bilinçlenmesi ile birlikte çocuklara erken dönemlerden itibaren gerek aileler tarafindan gerek bakım veren kimseler gerekse de eğitimciler tarafından sunulan imkanlar zenginleşmiş, matematik öğrenimi açısından kaliteli ve zengin oyuncaklar, imkanlar ve çeşitli materyaller sunulur hale gelmiştir (Taylor, 2013). Bu açıdan çocuklar, temel matematiksel kavramlarla ilgili bilgi sahibi olarak ve belirli düzeyde bir matematiksel anlayışa sahip bireyler olarak planlı eğitim ortamlarına gelirler (Akman, 2002; Nunes ve Bryant, 1997).

Tüm öğrenmeler bilinen ve bilinmeyen unsurlar üzerine inşa edilir. Çocukların sahip oldukları ön öğrenmeler ileriki öğrenmelere temel teşkil edebilir. Ön bilgiler, yürütülecek olan eğitim faaliyetlerinde başlangıç noktasına veya bilginin transferi sürecinde etkili araçlara dönüşebilir (Olkun, Fidan ve Özer-Babacan, 2015). Ancak, çocukların sahip oldukları ön bilgilerin, bilimsel gerçeklerle veya yürütülecek olan eğitimsel uygulamalarla sunulacak olan bilimsel gerçeklerle uyuşmaması durumu da ortaya çıkabilir (Bingölbali ve Özmantar, 2012). Bu durumda yeni öğrenmelerin gerçekleşmesi engellenebileceği gibi, eksik veya yanlış öğrenmenin hâkim olduğu durumda eksik veya yanlış öğrenmenin devam etmesi de beklenebilir (Campbell ve Campbell, 2008).
Çocukların erken matematik deneyimleri sayesinde edindikleri bilgi birikimi düşünüldüğünde bazı sorunlara da hazırlıklı olmamız gerekir (Baysen, Güneyli ve Baysen, 2012). Bu sorunlardan bir tanesi çocukların yaşadıkları deneyimler sonucu elde ettikleri yanlış bilgiler ve sahip oldukları yanlış inançlar sonucunda ortaya çıkan kavram yanılgılarıdır. Kavram yanılgısı bireyin sahip olduğu bilginin aslında başka bir kavram ya da bilgi türünü temsil ediyor olması ya da sahip olduğu bilginin bilimsel gerçeklikle uyuşmamasıdır (Yenilmez ve Yaşa, 2008).

Kavram yanılgıları çocukların zihin ve inanç dünyalarında bir bütünlük oluşturup, kendisine günlük yaşam deneyimleri içerisinde yer bulduğu sürece artık değiştirilmesi veya ortadan kaldırılması güç bir hal alabilir. $\mathrm{Bu}$ olumsuz durum, birbirleri ile ilişkili olan farklı kavramların kazanılması veya ileriki öğrenmelerin tam olarak gerçekleşmesi durumlarını da olumsuz yönde etkileyebilir (Yenilmez ve Yaşa, 2008). Bunun yanında, büyük oranda kavram yanılgılarının varlığı sebebiyle ortaya çıkan ve çocukların matematiksel kavram ve olguları yanlış bir şekilde kavramalarına, matematiksel düşünme ve uygulama süreçlerinde yanlışlıklar yapmalarına sebep olan "Hata" ise, çocukların matematiksel kavramları kazanma sürecinde yaşadıkları diğer bir sorundur (Bingölbali ve Özmantar, 2012).

Çocuklar matematiksel kavramlar ve ilişkiler açısından bazı hatalar yapabilmektedirler. Çocukların yaptıkları hatalar genellikle matematiksel açıdan uygun olmayan zihinsel modeller geliştirme, prototip forma odaklanma, aşırı genelleme, süreç-nesne bağlantısı hatası şeklinde karşımıza çıkmaktadır (Ryan ve Williams, 2007). Küçük çocukların matematiksel kavram ve ilişkiler açısından hatalar yapmaları o kadar doğal bir durumdur ki, gelișimsel özellikleri doğrultusunda bazı hatalar önceden tahmin edilebilen ve aynı gelişim döneminde bulunan hemen tüm çocukların ortaya koydukları hatalardır (Frye vd., 2013).

Örnekler vermek gerekirse, şekil kavramları açısından bakıldığında 3-6 yaş aralığındaki çocuklar, geometrik şekillerin kenar ve köşe gibi geometrik özeliklerine dikkat etmekten çok genel görünüşlerine odaklanmakta, (AktaşArnas ve Arslan, 2010; Clements, Swaminathan, Hannibal ve Sarama, 1999; Elia ve Gagatsis, 2003) 4-6 yaş aralığındaki çocuklar çember ve daire şekillerinin kenar ve köşelerinin olduğu şeklinde yanlış bir anlayışa sahip olmakta, (Korkmaz, Karademir ve Korkmaz, 2017) 2-4 yaş aralığındaki çocuklar ise çember ve elips şekillerini birbirine karıştırmakla beraber, birbirine paralel iki kenarı olan tüm dörtgenleri dikdörtgen olarak nitelendirebilmekte, (Clements ve Sarama, 2000) 5-6 yaş aralığında dahi üçgen kavramına ilişkin çoğunlukla kavram yanılgılarına sahip olmakta, (Kesicioğlu, Alisinanoğlu ve Tuncer, 2011) genel olarak 3-6 yaş aralığındaki çocuklar geometrik kavramları anlamakta ve algilamakta zorlanmaktadırlar (Clements, 1999; Clements ve Sarama, 2011; Kesicioğlu, Alisinanoğlu ve Tuncer, 2011). Miktar kavramı açısından bakıldığında genel olarak 5-6 yaş aralığındaki çocuklar hata yapmaktadırlar (Erden, 2006). 4-6 yaş aralığındaki çocuklar yarım kavramının bir bütünün iki eş parçası olduğunu anlamakta zorlanmakta (Hunting ve Sharpley, 1988) 8 yaş öncesinde çocuklar paranın temsil ettiği değeri anlamakta oldukça zorlanmaktadırlar Guerriero ve Cairns, 2017). Yeryön kavramları açısından bakıldığında Rigar (1994) sağ ve 
sol kavramlarının ancak 8-9 yaş aralığında; Clark ve Klonofff (1990) ise 13 yaş civarında tam olarak oturtulabildiği ve öncesinde çocukların çoğunlukla karıştırdıklarını vurgulamıştır. Sayı kavramı açısından bakıldığında 6-7 yaş aralığında bile çocuklar iki basamaklı sayılarda basamak değerine dikkat etmeden yanlış telaffuzlarda bulunmaktadırlar (Gervasoni, 2003; Mohyuddin ve Khalil, 2016). 5-7 yaş aralığındaki çocuklar ise sayıları ritmik olarak saymakta başarılı olsalar da anlamlı saymada ve sayı-değer ilișkisi kurarak birebir eşleme yapmakta zorlanmaktadırlar (Olkun, Fidan ve ÖzerBabacan, 2015). Matematiksel açıdan zit kavramlara bakıldığında ise çocuklar 4-5 yaş aralığında bile tam olarak anlayış geliștiremezler, ancak ilerleyen yaş dönemlerinde geliştirebilirler (Phillips ve Pexman, 2015). Zaman kavramları açısından 6 yaş öncesinde çocuklar dün-bugünyarın kavramlarını birbirine karıştırmaktadır (Haciibrahimoğlu, 2014). Zaman kavramları ile ilgili genel olarak ise kavram karmaşası yaşamaktadırlar (Hacısalihoğlu-Karadeniz, 2013). Çocuklar ancak 6-7 yaş aralığında zaman kavramları ile ilgili matematiksel açıdan tutarlı anlayışlar geliştirebilmektedirler (Cockburn, 2005).

$\mathrm{Bu}$ gibi çeşitli matematiksel hataların ortaya çıkma sebepleri her ne kadar büyük oranda kavram yanılgılarının varlığı (Bingölbali ve Özmantar, 2012) olsa da çocukların yaptıkları hataların nedenleri çok çeşitli olabilmektedir. Bazen hatalar anlık durumlardan da kaynaklanabilmektedir. Bunun yanında çocukların sahip oldukları yanlış anlayışlar ve eksik bilgiler de yapılan hataların sebepleri arasında gösterilir (Cockburn, 2005). Matematiksel hataların nedenlerinin ortaya koyulması bazen ise çok zor ve hatta imkânsız olabilir. Ancak çocukların matematiksel hatalarının düzeltilmesi, matematiksel kavramlarla ilgili anlayışlarının doğru kavramsal yapılarla değiştirilmesi veya geliştirilmesi gerekir. Bunu yapabilmek için de çocukların matematiksel hatalarının derinlemesine incelenmesi şarttır. Ancak bu şekilde hatalara pedagojik açıdan en uygun müdahaleler yapılabilir (Ryan ve Williams, 2007).

Cockburn'a (2005) göre genel bir çerçeve çizmek gerekirse, çocukların matematiksel kavramlar ve ilişkiler açısından yaptıkları hataların, eğitimcilerden kaynaklanan nedenler, ögrenenlerden kaynaklanan nedenler ve matematiksel kavram veya görevin yapısından kaynaklanan nedenler olmak üzere üç farklı kategoride toplandığı görülür. Eğitimciler ve öğrenenlerden kaynaklı nedenler, deneyim, yetkinlik, bilgi, anlayış, hayal gücü, yaratıcılık, ruh hali, tutum ve özgüven özellikleri şeklinde aynı alt kategorilerde ele alınmaktadır. Matematiksel kavram veya görevin yapısından kaynaklanan nedenler ise matematiksel zorluk ve karmaşıklığ 1 , sunumla ilgili zorluk ve karmaşıklık ile dönüşümle ilgili zorluklar şeklinde 3 alt kategoride ele alınır.

Çocukların matematiksel kavram veya ilişkilerde yaptıkları hatalar, korkulacak, tedirgin olunacak veya her zaman için ortadan kaldırılması gereken durumlar değildir (Bell, 1993). Ortaya çıkan hatalar, çocukların matematiksel kavram veya ilişkileri daha iyi öğrenebilmeleri açısından bir öğrenme imkanına veya aracına dönüştürülebilir (Bell, 1993; Frye vd., 2013; Herholdt ve Saphire, 2014; Ryan ve Williams, 2007). Çocukların ortaya koydukları matematiksel hatalarla yüzleşmeleri aynı zamanda onlar için bir öz değerlendirme ve öz düzenleme firsatına dönüşür (NCCA
[National Council for Curriculum and Assessment], 2014). Ancak ortaya koyulan hataların eğitimsel anlamda olumlu yönde kullanılabilmesi için eğitimcilerin hatalara ilişkin farkındalık geliştirmiş olmaları ve üstesinden gelinmesi sürecinde çocuklara destek olmaları gerekir (Frye vd., 2013; NCCA, 2014).

$\mathrm{Bu}$ araştırma ile okul öncesi öğretmenlerinin, çocukların matematiksel kavramlarla ilgili olarak sıklıkla yaptıkları hatalar hakkındaki görüşlerinin incelenmesi amaçlanmıştır. Araştırmanın alt amaçları olarak ise, çocukların yaptıkları hataların türleri, hataların olası nedenleri ve giderilmesine yönelik stratejiler ile ilgili görüşlerinin incelenmesi amaçlanmıştır. Öğretmen görüşlerinin ortaya çıkarılması, çocuklara bu yönde sunulabilecek olan eğitimsel faaliyetlerin daha verimli ve etkili bir şekilde planlanması, uygulanması, çocukların yaptıkları hataların giderilmesi ve sonuç olarak ise hataların birer kaliteli öğrenme deneyimine dönüştürülebilmesi açısından önemli olduğu düşünülmektedir.

Araştırmanın problemini, “Okul öncesi öğretmenleri, çocukların matematiksel kavramları kazanma süreçlerinde yaptıkları hatalarla ilgili neler düşünmektedir?" sorusu oluşturmaktadır. Araştırmanın alt problemlerini işe aşağıda sıralanan alt sorular oluşturmaktadır;

- Okul öncesi öğretmenlerine göre, okul öncesi dönemdeki çocuklar en çok hangi matematiksel kavramlara ilişkin hatalar yapmaktadır?

- Okul öncesi öğretmenlerine göre, okul öncesi dönemdeki çocuklar matematiksel kavramlara ilişkin ne tür hatalar yapmaktadır?

- Okul öncesi öğretmenlerine göre, okul öncesi dönem çocukların matematiksel kavramlara ilişkin hatalarının olası nedenleri nelerdir?

- Okul öncesi öğretmenleri, okul öncesi dönem çocukların matematiksel kavramlara ilişkin hatalarını gidermek için ne tür stratejiler kullanmaktadır?

\section{Yöntem}

Çalışmanın bu bölümünde araştırmanın deseni, çalışma grubu, veri toplama araçları ve veri analiz yöntemleri açıklanmıştır.

\subsection{Araştırmanın Deseni}

$\mathrm{Bu}$ çalışmada, okul öncesi öğretmenlerinin görüşleri doğrultusunda, çocukların kazanım sürecinde en çok hata yaptıkları kavramların, çocukların hatalarının olası nedenlerinin ve hataların giderilmesi için uygulanan stratejilerin belirlenmesi amacıyla nitel araştırma yöntemlerinden Olgubilim Deseni tercih edilmiştir. Olgubilim araştırmalarında hedef kitlenin kişisel deneyimleri ve bakış açısı çerçevesinde bir olguyu nasıl gördüğü, nasıl anladığ1 veya anlamlandırdığı ortaya çıkarılmaya çalışılır (Türkdoğan, 2014). Bu araştırmada ise olgu olarak öğretmenlerin mesleki deneyimleri çerçevesinde karşılaştıkları ve çocukların matematiksel kavramlara ilişkin sıklıkla yaptıkları hatalar ele alınmıştır. 


\section{2. Çalışma Grubu}

$\mathrm{Bu}$ araştırmaya gönüllü katılım esasına dayalı olarak ülkemizin Karadeniz Bölgesinde, Orta Karadeniz bölümünde yer alan bir ilde devlete bağlı 10 farklı resmi okul öncesi eğitim kurumunda 2017-2018 eğitim öğretim yılında görev yapan; sınıflarında 4 ile 5 yaş aralığında çocuklar bulunan (karma yaş grubu) ve 4 ile 23 yıl arasında değişen okul öncesi öğretmenliği deneyimi olan toplam 16 okul öncesi öğretmeni katılmıştır. Katılımcıların belirlenmesinde amaçsal örnekleme yöntemlerinden Kolay Ulaşılabilir Durum Örneklemesi (Convenience Sampling) kullanılmıştır. Kolay ulaşılabilir durum örneklemesinde, katılımcılara ulaşmanın maliyet ve zaman yönünden ekonomik olması dikkate alınır (McMillian ve Schumacher, 2010). Böylelikle araştırmacı kendisine yakın ve ulaşııısı kolay olan kişilerle çalışma şansına sahip olduğu için araştırmanın daha hızlı ve pratik bir şekilde gerçekleştirilmesi sağlanır (Yıldırım ve Şimşek, 2011). Bu araştırmada ise katılımı beklenen öğretmenlerin belirlenmesinde, öğretmenlerin görev yaptıkları kurumların araştırmacıların görev yaptıkları kuruma yakın olmaları, hali hazırda çeşitli resmi protokollere dayalı iş birliği ve iletişim halinde olmaları sebebiyle araştırmanın yürütülebilmesi noktasında pratiklik sağlayabileceği düşünceleri belirleyici olmuştur. Araştırmaya katılan öğretmenlere ait demografik bilgiler Tablo 1'de sunulmuştur.

Tablo 1. Katılımcılara İlişkin Demografik Bilgiler

\begin{tabular}{|c|c|c|c|}
\hline $\begin{array}{l}\text { Demografik } \\
\text { Bilgiler } \\
\end{array}$ & Kategoriler & $f$ & $\%$ \\
\hline \multirow{3}{*}{ Cinsiyet } & Kadın & 13 & 81,25 \\
\hline & Erkek & 3 & 18,75 \\
\hline & Toplam & 16 & 100 \\
\hline \multirow{3}{*}{ Lise Ö̆grenimi } & K1z Meslek Lisesi & 8 & 50 \\
\hline & Diğer Liseler & 8 & 50 \\
\hline & Toplam & 16 & 100 \\
\hline \multirow{3}{*}{ Lisans Öğrenimi } & Açık Öğretim Fakültesi & 5 & 31,25 \\
\hline & Eğitim Fakültesi & 11 & 68,75 \\
\hline & Toplam & 16 & 100 \\
\hline \multirow{10}{*}{ Mesleki Deneyim } & $4 \mathrm{Y}_{11}$ & 2 & 12,5 \\
\hline & $5 \mathrm{Y} 1 \mathrm{l}$ & 3 & 18,75 \\
\hline & $6 \mathrm{Y} 11$ & 1 & 6,25 \\
\hline & 7 Y1l & 1 & 6,25 \\
\hline & 8 Yil & 3 & 18,75 \\
\hline & $12 Y_{11}$ & 1 & 6,25 \\
\hline & $14 Y_{11}$ & 3 & 18,75 \\
\hline & 16 Y1l & 1 & 6,25 \\
\hline & $23 \mathrm{Y}_{11}$ & 1 & 6,25 \\
\hline & Toplam & 16 & 100 \\
\hline
\end{tabular}

\subsection{Veri Toplama Araçları}

Araştırma kapsamında okul öncesi öğretmen görüşleri açısından, çocukların kazanma süreçlerinde sıklıkla hata yaptıkları matematiksel kavramları belirlenmesi amacıyla, öğretmenlere Millî Eğitim Bakanlığı Okul Öncesi Eğitim Programı'nda belirtilen tüm matematiksel kavramlar temel alındığı ve araştırmacılar tarafından geliştirilen "Okul Öncesi Dönemdeki Çocukların Matematiksel Kavramlara İlişkin Genel Hataları" başlıklı bir envanter sunulmuştur. Ek 1'de örneği bulunan envanter, okul öncesi eğitim programda yer alan ve çocukların kazanmaları beklenen "Şekil", "Boyut", "Miktar", "Yer-Yön", "Say1", "Zıt
Kavramlar" ve "Zaman" kavram grupları altında belirtilen alt kavramların (MEB, 2013) listelenmesi ile oluşturulmuştur. Envanterin oluşturulmasında okul öncesi eğitim alanında uzman bir akademisyenin ve matematik eğitimi alanında uzman bir akademisyenin uzman görüşlerine başvurulmuştur. Oluşturulan bu envanter ile öğretmenlerden çocukların her bir matematiksel kavram ve alt kavramla ilgili olarak hata yapma sıklkları ile ilgili olarak "Hiçbir Zaman", "Çok Nadir", "Bazen", "Çoğunlukla" ve "Her Zaman" seçeneklerinden birini işaretleyerek görüşlerini belirtmeleri beklenir.

Öğretmenlerin, çocuklar tarafından sıklıkla yapılan hataların türü, nedenleri ve giderilmesine yönelik stratejiler ile ilgili görüşlerinin derinlemesine incelenmesi amacıyla, araştırmacılar tarafından geliştirilen "Çocukların Matematiksel Kavramlara İlişkin Genel Hataları Öğretmen Görüşme Formu" başlıklı bir yarı yapılandırılmış görüşme formu kullanılmıştır. Bu form her bir matematiksel kavram için ayrı ayrı uygulanması gereken ve belirtilen hatalarla ilgili derinlemesine inceleme yapılmasını sağlayacak 3 farklı yarı yapılandırılmış görüşme sorusundan oluşmaktadır. Görüşme formu ile yöneltilen yarı yapılandırılmış görüşme soruları Tablo 2'de paylaşılmıştır.

Tablo 2. Yarı Yapılandırılmış Görüşme Soruları

\begin{tabular}{ll}
\hline Boyut & Görüşme Sorusu \\
\hline Hata Türü & $\begin{array}{l}\text { Çocuklar ........ kavramına ilişkin ne tür hatalar } \\
\text { yapmaktadır? }\end{array}$ \\
Hata Nedeni & $\begin{array}{l}\text { Sizce çocukların belirttiğiniz hatayı yapma } \\
\text { nedenleri nelerdir? }\end{array}$ \\
Giderilme & $\begin{array}{l}\text { Çocukların yaptı̆̆ bu hatanın giderilmesi için } \\
\text { Stratejisi }\end{array}$ \\
\hline
\end{tabular}

\subsection{Verilerin Toplanmas1}

Çalışmanın veri toplama sürecinde ilk olarak, katılım konusunda gönüllüllük gösteren öğretmenlere Çocukların Matematiksel Kavramlara İlişkin Genel Hataları envanteri sunulmuştur. Öğretmenlerden okul öncesi dönemdeki çocukların kazanma süreçlerinde sıklıkla hata yaptıkları matematiksel kavramları belirtmeleri istenmiştir. Öğretmenlere diledikleri zaman diliminde ve diledikleri sürede formları doldurabilecekleri ve diledikleri zaman teslim edebilecekleri hatırlatılmıştır.

Öğretmen görüşleri açısından çocukların sıklıkla hata yaptıkları belirlenen matematiksel kavramlar doğrultusunda şekillenen Çocukların Matematiksel Kavramlara İlişsin Genel Hatalarl Ögretmen Görüsme Formu, her bir öğretmenle yürütülen birebir görüşmelerde uygulanmıştır. Görüşmelerde öğretmenlerin yalnızca şu an itibariyle öğretmeni oldukları sınıflarda bulunan çocukların yaptığ matematiksel hataları değil, mesleki yaşamları boyunca karşılaştıkları vaka örneklerini düşünerek ve tecrübelerini gözden geçirerek cevaplar vermeleri istenmiştir. Görüşmeler yalnızca yazılı olarak kayıt altına alınmıştır. Yürütülen birebir görü̈şmeler, her öğretmenin daha önce belirttiği matematiksel kavramların sayısına göre değişmekle beraber 10 ile 30 dakika arasında sürmüştür.

\subsection{Verilerin Analizi}

$\mathrm{Bu}$ araştırmada iki farklı veri toplama aracı kullanılmıştır. $\mathrm{Bu}$ araçlardan birisi olan envanter uygulaması ile 
çocukların kazanma süreçlerinde, diğer seçeneklere göre ortaya çıkma sıklığı daha yüksek olan yani öğretmen görüşleri açısından çocukların "Çoğunlukla" ve "Her Zaman" hata yaptığı düşünülen matematiksel kavramlar belirlenmiştir. Veriler belirlenen kavramları dile getiren öğretmenlerin kodlarının sıralanması (listelenmesi) şeklinde ortaya koyulmuştur.

Sıklıkla hata yapılan kavramların belirlenmesi üzerine gerçekleştirilen görüşmelerde kullanılan görüşme formu ile edilen verilerin analizinde ise nitel veri analiz tekniklerinden biri olan $\dot{I}_{c ̧ e r i k}$ Analizi tekniği kullanılmıştır. İçerik analizi tekniği, dolaylı yollarla insan davranışlarını anlama firsatı sunar. İçerik analizi; bir metinde yer alan kelimelerin veya kavramların varlığını ve ilişkilerini belirlemek amacıyla, metnin belirli kurallara dayalı kod ve kategorilerle özetlendiği sistematik ve yinelenebilir bir tekniktir (Büyüköztürk vd., 2011). İçerik analizinde temel amaç, toplanan verileri açıklayabilecek kavramlara ve ilişkilere ulaşmaktır (Yıldırım \& Şimşek, 2011).

İçerik analizinin kullanıldığı araştırmalarda güvenirliğin sağlanması amacıyla, farklı araştırmacıların yaptığı kodlamaların güvenirliğine ilişkin bir çalışma yapmak gerekir. Bu durumda araştırmacılar aynı veri setini kodlar ve ortaya çıkan kodlama benzerliklerini tüm kodlama sayısına oranlayarak bir kodlama yüzdesine ulaşırlar. Bu tür çalışmalarda kodlama güvenirlik değerinin en az \%70 değerine ulaşması beklenir (Yıldırım \& Şimşek, 2011).

\section{6. İnanılırlık ve Tutarlı11k}

$\mathrm{Bu}$ araştırmanın iç geçerliğini etkileyebileceği düşünülen bazı tehditler karşısında önlemler alınmıştır. Araştırmaya katılım konusunda gönüllülük esasının temel alındığı vurgulanmış ve araştırmaya katılımı beklenen öğretmenlerle bu yönde görüşmeler yapılmıştır. Okul öncesi öğretmenlerine öncelikle araştırmanın amacı, kapsamı ve gerçekleştirilme şekli ile ilgili bilgiler verilmiştir. Elde edilmesi planlanan verilerin yalnızca bu bilimsel araştırma kapsamında, bilimsel ve etik kurallar çerçevesinde değerlendirileceği, herhangi bir şekilde üçüncü kişilerle paylaşılmayacağı hatırlatılmıştır. Öğretmenlerin gönüllü katılımının desteklenmesi amacıyla onlardan kimliklerini ortaya çıkarabilecek hiçbir özel bilgi talep edilmemiş ve bu yönde bir uygulama yapılmayacağ taahhüt edilmiştir. Ayrıca katılım konusunda gönüllülük gösterseler dahi diledikleri an araştırmadan çıkma haklarının olduğu, bu durumda ölçme araçları ile elde edilen verilerin kendilerine iade edileceği vurgulanmıştır. Öğretmenlerin kendilerini rahat hissetmeleri açısından birebir görüşmeler yalnızca yazılı olarak kayıt altına alınmış ve görüşme zamanı ve yeri makul ölçülerde öğretmenlerin ayarlamalarına bırakılmıştır. Öğretmenlere sunulan formlarda, öğretmenlerin görüşlerinin sınırlandırılmaması ve görüşlerini derinleştirmelerine destek olunması amacıyla kendilerine yöneltilen sorulara, hata yapılan kavramlar, hata türleri, hata nedenleri ve giderilme stratejileri açısından birden çok cevap verebilecekleri belirtilmiştir. $\mathrm{Bu}$ açıdan çalışmaya katılan öğretmen sayısı 16 ile sınırlı kalmasına rağmen öğretmenlerimizden gelen fikirler kimi zaman katılımcı sayısından çok daha fazla sayıya ulaşabilmiştir.
Elde edilen verilerin güvenirliğinin sağlanması açısından ise her bir öğretmen ile yapılan birebir görüşmeler sonunda öğretmenlere, sorular ile birlikte verdikleri cevaplar tekrar hatırlatılmış ve teyit etmeleri sağlanmış, yanlış anlaşılan veya öğretmenler tarafından tekrar düzeltilmek, değiştirilmek istenen hususlar düzeltilerek görüşmeler sonlandırılmıştır. Görüşmeler ile elde edilen verilerin analizi açısından okul öncesi eğitimi ve okul öncesi eğitimde ölçme ve değerlendirme alanlarında uzman iki farklı araştırmacının analizine başvurularak kodlayıcı güvenirliği sağlanmıştır. Araştırmacıların farklı zamanlarda yaptıkları kodlamalar karşılaştırılmış ve kodlama güvenirlik yüzdesi \%85,4 olarak bulunmuştur. Bu sonuçlara göre kodlayıcı güvenirliğin sağlandığı söylenebilir (Yıldırım \& Şimşek, 2011). Araştırmacılar tekrar bir araya gelerek \%14,6'lık uyuşmazlığa neden olan kodlamaları incelemiş ve bu kodlamalar incelendikten sonra görüş birliğine varılarak uyuşmazlık giderilmiştir. Daha sonra bu veriler belirlenen kategoriler altında sinıflandırılarak tablolar halinde sunulmuştur.

\section{Bulgular}

Araştırmaya katılan okul öğretmenlerinin, kazanım sürecinde çocuklar tarafindan "Çoğunlukla" ve "Her Zaman" için hata yapıldığını düşündükleri matematiksel kavramlar, öğretmen görüşleri açısından çocuklar tarafindan sıklikla hata yapılan matematiksel kavramlar olarak ele alınmıştır. $\mathrm{Bu}$ bölümde öğretmen görüşleri açısından çocuklar tarafından sıklıkla hata yapılan matematiksel kavramlar, hataların türü, hataların kaynakları ve nedenleri ile giderilme stratejilerine ilişkin bulgular ayrı başlıklar altında ele alınmıştır.

\section{1. Çocukların Sıklıkla Hata Yaptıkları Matematiksel Kavramlara İlişkin Bulgular}

Öğretmen görüşleri açısından çocukların kazanım sürecinde sıklıkla hata yaptıkları matematiksel kavramlar ve hata yapıldığını dile getiren öğretmenlerin kodları listelenmiştir. Ortaya çıkan kavram ve alt kavramların dağılımı Tablo 3 'te sunulmuştur. 
Tablo 3. Sıklıkla Hata Yapılan Matematiksel Kavramlar

\begin{tabular}{|c|c|}
\hline Kavramlar - Alt Kavramlar & Katılımcilar \\
\hline Kenar & Ö5,Ö7,Ö9,Ö10,Ö11,Ö12,Ö13,Ö14 \\
\hline Çember & Ö5,Ö6,Ö8,Ö9,Ö10,Ö12,Ö14 \\
\hline$=$ Daire & Ö6,Ö9,Ö10,Ö11,Ö12 \\
\hline Dikdörtgen & Ö5,Ö7,Ö10,Ö11,Ö12 \\
\hline Elips & Ö4,Ö8,Ö9,Ö14,Ö15 \\
\hline Köşe & Ö5,Ö7,Ö10 \\
\hline Kare & Ö10,Ö11 \\
\hline ص Geniş-Dar & Ö7,Ö9 \\
\hline İnce-Kalın & Ö10 \\
\hline Para & Ö1,Ö2,Ö6,Ö7,Ö11,Ö13 \\
\hline Tek -Çift & Ö4,Ö5,Ö7,Ö11,Ö15 \\
\hline \# Kalabalık- Tenha & Ö3,Ö7,Ö14 \\
\hline Eşit & Ö4,Ö7,Ö10 \\
\hline ¿ Parça- Bütün & Ö4,Ö15 \\
\hline Tam- Yarım & Ö4 \\
\hline Ağır-Hafif & Ö12 \\
\hline Sağ-Sol (Sağında-Solunda) & $\begin{array}{l}\text { Ö1,Ö2,Ö3,Ö5,Ö9,Ö10,Ö12,Ö13,Ö14,Ö } \\
\text { 15,Ö16 }\end{array}$ \\
\hline : Oี Önünde-Arkasında & Ö1 \\
\hline İçinde-Dışında & Ö1 \\
\hline$\doteq$ Arasinda & Ö6 \\
\hline Alçak-Yüksek & Ö14 \\
\hline Uzak-Yakın & Ö10 \\
\hline $10-20$ arası sayılar & Ö3,Ö5,Ö7,Ö8,Ö9,Ö10,Ö12,Ö13,Ö15 \\
\hline Önceki Sonraki & Ö1,Ö3,Ö10,Ö11 \\
\hline İlk-Orta-Son & Ö7,Ö10,Ö12 \\
\hline ต็ Sira sayis1 & Ö3,Ö14 \\
\hline Sifir & Ö8,Ö14 \\
\hline $1-10$ arası sayılar & Ö3 \\
\hline $\mathbf{N}$ Derin-Sı̆̆ & Ö2,Ö4,Ö6,Ö7,Ö10,Ö12,Ö13,Ö14 \\
\hline Benzer & Ö1,Ö2,Ö6,Ö12,Ö13,Ö14 \\
\hline \multirow{2}{*}{ 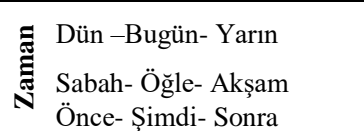 } & $\begin{array}{l}\text { Ö1,Ö3,Ö5,Ö6,Ö7,Ö8,Ö9,Ö10,Ö11,Ö12, } \\
\text { Ö13,Ö14,Ö16 }\end{array}$ \\
\hline & $\begin{array}{l}\text { Ö2,Ö3,Ö11,Ö13 } \\
\text { Ö1,Ö3,Ö10 }\end{array}$ \\
\hline
\end{tabular}

B: Boyut, Z: Zitlik

Tablo 3 incelendiğinde, öğretmen görüşleri açısından çocukların çeşitli matematiksel kavramların kazanımı sürecinde sıklıkla hatalar yapıldığı görülmektedir. Matematiksel kavram kategorileri açısından ise şekil, miktar, yer-yön, sayı ve zaman kavramlarının öğretmenlerin büyük çoğunluğu tarafindan hata yapılan kavramlar olarak dile getirildiği; yine zit kavramların öğretmenlerin çoğunluğu tarafından dile getirilmekle beraber boyut kavramlarının öğretmenlerin çok azı tarafından dile getirildiği görülmektedir. Daha detaylı incelenecek olursa, şekil kavramları açısından çoğu öğretmenin kenar ve çember kavramını hata yapılan kavramlar olarak dile getirdikleri; bununla beraber öğretmenlerin azımsanmayacak bir bölümü tarafindan daire, dikdörtgen, elips kavramlarının, az bir bölümü tarafından ise köşe ve kare kavramlarının hata yapılan kavramlar olarak dile getirildiği görülür. Boyut kavramları açısından öğretmenlerin az bir bölümünün geniş-dar ve ince-kalın kavramlarını dile getirdikleri görülür. Miktar kavramları açısından öğretmenlerin azımsanmayacak bir bölümünün para ve tek-çift kavramlarını; az bir bölümünün ise kalabalık-tenha, eşit, parça-bütün, tam-yarım ve ağırhafif kavramlarını kazanım sürecinde çocuklar tarafından sıklıkla hata yapılan kavramlar olarak dile getirdikleri görülür. Yer yön kavramları açısından ise öğretmenlerin büyük bir çoğunluğunun sağ-sol kavramını sıklıkla hata yapılan kavramlar olarak dile getirdikleri bunun yanında öğretmenlerin çok azının önünde-arkasında, içinde-dışında, arasına, alçak-yüksel ve uzak-yakın kavramlarını dile getirdikleri görülür. Sayı kavramlarına bakıldığında öğretmenlerin çoğunun 10-20 arası sayıları çocuklar tarafından sıklıkla hata yapılan kavramlar olarak dile getirdikleri; öğretmenlerin az bir bölümünün ise öncekisonraki, ilk-orta-son, sıra sayıs1, sıfir ve 1-10 arası sayıları hata yapılan kavramlar olarak dile getirdikleri görülür. Z1t kavramlar açısından ise katılımcı öğretmenlerin yarısının derin-sı̆̆ kavramlarını, azımsanmayacak bir bölümünün ise benzer kavramını çocuklar tarafindan sıklıkla hata yapılan kavramlar olarak dile getirdiği görülür. Zaman kavramları açısından öğretmenlerin büyük bir çoğunluğunun dünbugün-yarın kavramlarını, az bir bölümünün ise sabah-öğleakşam ve önce-şimdi-sonra kavramlarını çocuklar tarafindan sıklıkla hata yapılan kavramlar olarak dile getirdikleri görülür.

Bunun yanında, ülkemizde uygulanmakta olan okul öncesi eğitim programında belirtilen ve dolayısıyla katılımcı öğretmenlere sunulan envanterde bulunan matematiksel kavramların tamamı düşünüldüğünde Tablo 3'te sayı kavramları altındaki tüm kavramların öğretmen görüşleri açısından, çocuklar tarafindan sıklıkla hata yapılan kavramlar arasında gösterildiği görülür. Şekil kavramı altındaki "üçgen" kavramının; boyut kavramı altındaki "büyük", "küçük", "orta" ve "uzun-kısa" kavramlarının; miktar kavramı altındaki "az-çok" ve "boş-dolu" kavramlarının; yer-yön kavramları altındaki "ön-arka", "yukarı-aşağı", "ileri-geri”, “alt-üst-orta”, “yanında”, "yukarıda-aşağıda", "iç-dış" ve "içeri-dışarı", kavramlarının; zıt kavramlar altında "aynı", "farklı”, "açıkkapalı", "hızlı-yavaş", “ters-düz”, "başlangıç-bitiş" ve "düz-eğri” kavramlarının; zaman kavramı altında ise gecegündüz kavramlarının kazanım sürecinde çocuklar tarafindan sıklıkla hata yapılan kavramlar arasında belirtilmediği görülür. Öğretmen görüşleri açısından ilgili kavramların kazanımı sürecinde çocukların, diğer matematiksel kavramlara göre nispeten daha az hata yaptıkları söylenebilir.

\section{2. Çocukların Sıklıkla Yaptıkları Hataların Türüne İlişkin Bulgular}

Öğretmen görüşleri açısından, çocukların matematiksel kavramlara ilişkin sıklıkla yaptıkları hataların türüne ait bulgular açısından oluşan kategoriler ve hata türlerini dile getiren öğretmenlerin kodları Tablo 4'te sunulmuştur.

Tablo 4. Yapılan Hataların Türleri

\begin{tabular}{ll}
\hline Hata Türleri & Katılımclar \\
\hline Kavram Karmaşas1 & Ö1,Ö2,Ö3,Ö4,Ö5,Ö6,Ö7,Ö8,Ö9,Ö10,Ö11,Ö \\
& 12,Ö13,Ö14,Ö15,Ö16 \\
Kavramı Özümseyememe & Ö1,Ö2,Ö3,Ö4,Ö5,Ö6,Ö7,Ö9,Ö10,Ö11,Ö12, \\
Kavramlar Arası İlişki & Ö1,Ö3,ÖÖ15,Ö16, Ö6,Ö7,Ö8,Ö9,Ö10,Ö11,Ö12, \\
Kuramama & Ö13,Ö14,Ö15 \\
Kavram Yanılgıs1 & Ö1,Ö2,Ö3,Ö4,Ö5,Ö6,Ö8,Ö9,Ö10,Ö11,Ö12, \\
Kavramı Yanlıs Kullanma & Ö13,Ö14,Ö3,Ö6,Ö7,Ö8,Ö9,Ö10,Ö12,Ö13,Ö14 \\
Odaktan Uzaklaşamama & Ö2,Ö4,Ö7,Ö6,Ö10,Ö12 \\
Aşır1 Genelleme & Ö5,Ö7,Ö8,Ö10 \\
Herhangi Bir Kategoriye & Ö4, Ö11 \\
Yerleştirilemeyen & \\
Herhangi Bir Hata Türü & Ö13 \\
Belirtmeme &
\end{tabular}

Tablo 4 incelendiğinde, çocukların matematiksel kavramların kazanımı sürecinde yaptıkları hataların türü olarak, katılımc1 öğretmenlerin tamamının kavram karmaşasını, büyük çoğunluğunun kavramı özümseyememe 
ve kavramlar arası ilişki kuramamayı, çoğunluğunun kavram yanılgısı ve kavramı yanlıș kullanmayı dile getirdikleri görülür. Öğretmenlerin azımsanmayacak bir bölümünün odaktan uzaklaşamamayı, az bir bölümünün ise aşırı genellemeyi dile getirdikleri görülür. İki farklı öğretmenin iki farklı hata durumu açısından dile getirdikleri hata türleri herhangi bir kategoriye yerleștirilemezken, bir katılımcının ise bir hata durumu açısından herhangi bir hata türü belirtmediği görülür.

Öğretmenler tarafindan ortaya koyulan hata türü olarak Kavram Karmaşasına örnek olarak Ö4 kodlu öğretmenin yaptığı "Sĭ̆ kelimesi ile sik kelimesi gibi diğer bazı kelimeleri karıştırıyorlar. Güncel kullanılan bir kelime

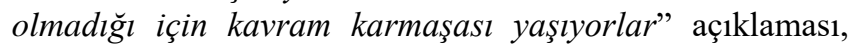
Ö10 kodlu öğretmenin "Referans noktası problem oluyor. Örneğin masanın să̆l senin solun oluyor. Onun için de să̆-sol, să̆ında solunda hep karışıyor" açıklaması ile Ö11 kodlu öğretmenin yaptığı "Kenar ve köşe kavramlarını karıştırlyorlar. Kenar yerine köşeyi gösteriyorlar" açıklamaları örnek gösterilebilir.

Kavramı Özümseyememe açısından ise Ö6 kodlu öğretmenin belirttiği "Çocuklar slğ kelimesini kullanmıyorlar. Onun yerine derin değil ifadesini kullanarak sı̆̆ kavramını kullanmayı reddediyorlar" ifadesi, Ö7 kodlu öğretmenin belirttiği " 17 'den sonra 18 geleceğini ezbere saylyorlar ama 17'den sonra 18 geleceğini mantıksal olarak kabul etmeyebiliyorlar" ifadesi ile Ö13 kodlu öğretmenin belirttiği "Kenar kavramını verirken şekillerin "sınırl" ifadelerini kullanıyoruz. Çocuklar ögretmenim çemberin sinırları bunlar değil mi diye sorabiliyorlar. Bu açıdan çemberin veya dairenin aslında kenarının olmadı̆̆ını özümsemeleri biraz geç oluyor" ifadeleri örnek gösterilebilir.

Kavramlar Arası İlişki Kuramama durumuna örnek olarak Ö3 kodlu öğretmenin zaman kavramları açısından belirttiği "Kelime ile zaman arasında ilişki kuramıyorlar" ifadesi, Ö9 kodlu öğretmenin belirttiği "Sayılarl 1'den 10'a kadar ögretiyoruz. Sonra iki basamaklı sayllarl öğretmeye çallşlyoruz. Çocuklar özellikle yazarken örneğin 12 yazarken 1 ve 2'yi çok ayrı yazabiliyor veya aralarına tire çekebiliyor. Sayı değeri ile basamak değerini bağdaştıramıyorlar" ifadesi ile Ö13 kodlu öğretmenin benzer kavramı açısından belirttiği "Nesnelerin benzerliklerini neye göre ayırt edebileceğini tespit etmede sıkıntı yaşlyorlar. Kavramlar arasında ilişki kuramıyorlar. Mesela kitap, kalem, defter ve tencere resmi sunulduğunda hepsinin cansiz olduğunu anlayabiliyorlar ama tencere haricindekilerin sınıfta kullanılan araçlar olduğu için benzer yönlerinin olduğunu bu yüzden ilişkili olduğunu anlamıyorlar" ifadesi örnek gösterilebilir.

Kavram Yanılgısına örnek olarak Ö1 kodlu öğretmenin benzer kavramı açısından belirttiği "benzer olanı bulun dediğimde aynisını bulmaları gerektiğini zannediyorlar. Aynı olanları bulmaya çalışıyorlar" ifadesi, Ö12 kodlu öğretmenin ağır-hafif kavramı açısından belirttiği "Nesnelerin cüssesine, görüntüsüne bakıp karar veriyorlar. Cüssesi büyük olanın ă̆ır veya küçük olanın hafif olacă̆ını sanıyorlar" ifadesi ile Ö8 kodlu öğretmenin dün-bugünyarın kavramları açısından belirttiği "Yarın şunu yapacă̆ız dediğimde gün içerisinde yapmamızı bekliyorlar. Yarını bugünün bir parçası zannediyorlar" ifadeleri örnek gösterilebilir.

Kavramı Yanlış Kullanma kategorisi için ise Ö10 kodlu öğretmenin derin-sığ kavramları açısından belirttiği "Çoğu zaman derin ve siğ kavramlarının ne anlama geldiğini bilmedikleri gibi, derin yerine çok su var, siğ yerine az su var diyorlar" ifadesi, Ö13 kodlu öğretmenin dün-bugünyarın kavramları açısından belirttiği "Yarın gitmiştik gibi yanlış şeyler söylüyorlar. Zaman kavramlarını yerinde kullanamıyorlar. Kavramları doğru zaman için yerine oturtamıyorlar" ifadesi ile Ö14 kodlu öğretmenin kalabalık-tenha kavramları açısından belirttiği "Kalabalık ve tenha kavramlart yerine az insan-çok insan diyorlar. Azçok kavramlarını kullanıyorlar" ifadesi örnek gösterilebilir.

Odaktan Uzaklaşamama kategorisi için Ö7 kodlu öğretmenin ilk-orta-son kavramları açısından dile getirdiği "Çocuklara orta kavramını hep üç adet nesne ile ögretiyoruz. Çoklu siralamalarda ortadakini bulamiyorlar. Ortasi yok ki şeklinde ifadeleri oluyor. Üçlü sırada ortada olması gerektiğine takılıp kalıyorlar" ifadesi ile Ö10 kodlu öğretmenin yine ilk-orta-son kavramları açısından dile getirdiği "Orta noktayı bulamıyorlar. Mesela yedi boncuk aldın. Ortadaki hangisi desem gösteremiyor. Çünkü hep üçü sırada ortayı göstermeye alışmış" ifadesi ile Ö12 kodlu öğretmenin tekrar ilk-orta-son kavramları açısından dile getirdiği "İlk-son kavramları ile üçlü dizilerde orta kavramı iyi ama sayı artınca karıştırıyorlar. Hep üçlüdeki gibi iki yanında nesne ve ortasındakini arıorlar" ifadesi örnek gösterilebilir.

Aşırı Genelleme kategorisine örnek olarak Ö5 kodlu öğretmenin "Çember ve dairenin ayrımını yapamıorlar. Çember veya daire olsun her dairesel şekle yuvarlak diyorlar" ifadesi; Ö7 kodlu öğretmenin tek-çift kavramları açısından dile getirdiği "Çocuklar, 1 tane ise tektir çok ise çifttir şeklinde düşünüyorlar” ifadesi örnek gösterilebilir.

Son olarak Herhangi Bir Kategoriye Yerleştirilemeyen kategorisinde değerlendirilen ifadelere örnek olarak Ö4 kodlu öğretmenin hata türü yerine hatanın nedeninin çağrıştıran "basit parçaları yapıyorlar ama zor parçaları yapamıyorlar" ifadesi ile Ö11 kodlu öğretmenin belirttiği ve temelde herhangi bir hata ifade etmeyen "Çocuklara 6'dan önce ne gelir? diye sorduğumuzda hemen cevap veremiyorlar. Tekrar 1'den 6'ya kadar sayıp anca 5 cevabını veriyorlar" ifadesi örnek gösterilebilir.

3.3. Çocuklar Tarafından Sıklıkla Yapılan Hataların Kaynakları ve Nedenlerine İlişkin Bulgular

Öğretmen görüşleri açısından, çocukların kazanım sürecinde matematiksel kavramlara ilişkin yaptıkları hataların kaynakları ve nedenleri incelenmiş ve verilerin ulaşılan kategorilere göre dağılımı Tablo 5'te gösterilmiştir. 
Tablo 5. Yapılan Hataların Kaynakları ve Nedenleri

\begin{tabular}{|c|c|c|}
\hline \multicolumn{2}{|c|}{ Hatanın Kaynağı - Nedeni } & Katılımcılar \\
\hline \multirow{7}{*}{ 导 } & Öğretim İlkelerine Uyulmaması & $\begin{array}{l}\text { Ö1,Ö3,Ö4,Ö7,Ö9,Ö10,Ö12,Ö1 } \\
\text { 3,Ö14 }\end{array}$ \\
\hline & Kavramın Ele Almaması & Ö7,Ö9,Ö10,Ö12,Ö13,Ö14,Ö15 \\
\hline & Kavramın Yanlış Kullanımı & Ö3,Ö7,Ö8,Ö9,Ö12,Ö13 \\
\hline & Yanlış Materyal Tercihi & Ö1,Ö7,Ö10,Ö11 \\
\hline & Bilgiyi Yanlış Aktarma & Ö5,Ö9,Ö10,Ö13 \\
\hline & Yanlış Öğretim Yöntemi Tercihi & Ö1,Ö2,Ö3 \\
\hline & Uygun Yöntemi Bilememe & Ö13 \\
\hline \multirow{6}{*}{ ن̈. } & Bilişsel Düzeyin Yetersizliği & $\begin{array}{l}\text { Ö1,Ö2,Ö3,Ö4,Ö5,Ö6,Ö7,Ö8,Ö } \\
\text { 9,Ö10,Ö11,Ö12,Ö13,Ö14,Ö15, } \\
\text { Ö16 }\end{array}$ \\
\hline & Deneyim Eksikliği & $\begin{array}{l}\text { Ö1,Ö2,,Ö3,Ö4,Ö5,Ö6,Ö7,Ö8,Ö } \\
\text { 10,Ö11,Ö12,Ö13,Ö14 }\end{array}$ \\
\hline & Ön Koşul Öğrenme Eksikliği & $\begin{array}{l}\text { Ö1,Ö3,Ö4,Ö55,Ö6,Ö7,Ö10,Ö11, } \\
\text { Ö12,Ö14 }\end{array}$ \\
\hline & Sözcük Dağarcığının Yetersizliği & Ö2,Ö3,Ö10,Ö11 \\
\hline & Motivasyon Düzeyi & Ö5,Ö12,Ö15 \\
\hline & Bilgiyi Transfer Edememe & Ö10,Ö14 \\
\hline \multirow{4}{*}{$\underline{1}$} & \multirow[b]{2}{*}{ Diğer Kavramlarla Benzeı } & $\begin{array}{l}\text { Ö1,Ö3,Ö4,Ö5,Ö6,Ö7,Ö8,Ö10, } \\
\text { Ö11,Ö12,Ö14,Ö15,Ö16 }\end{array}$ \\
\hline & & $\begin{array}{l}\text { Ö3,Ö5,Ö6,Ö7,Ö9,Ö10,Ö11,Ö1 } \\
\text { 4,Ö14,Ö15 }\end{array}$ \\
\hline & Kavramın Güncel Olmaması & $\begin{array}{l}\text { Ö4,Ö5,Ö6,Ö7,Ö8,Ö10,Ö11,Ö1 } \\
\text { 2,Ö14 }\end{array}$ \\
\hline & Kavramın Zorluğu & $\begin{array}{l}\text { Ö2,Ö6,Ö7,Ö10,Ö11,Ö12,Ö13, } \\
\text { Ö14 }\end{array}$ \\
\hline 4 & Kavramın Yanlış Kullanımı & Ö1,Ö7,Ö9,Ö10,Ö12 \\
\hline & Kavramın Yanlıș Kullanımı & Ö9 \\
\hline
\end{tabular}

KD: Kavramın Doğası A: Aile, T: Toplum

Tablo 5 incelendiğinde, öğretmenlerin, okul öncesi dönemdeki çocukların kazanım sürecinde matematiksel kavramlara ilişkin yaptıkları hataların kaynakları olarak kendilerini (Eğitimci), çocukları, kavramın doğasını, aileyi ve toplumu gördükleri anlaşılır. Öğretmenler tarafından dile getirilme sıklığı açısından bakıldığında ise sırasıyla, çocuklardan kaynaklanan nedenlerin, kavramın doğasından kaynaklanan nedenlerin, eğitimcilerden kaynaklanan nedenlerin, aileden kaynaklanan nedenlerin ve toplumdan kaynaklanan nedenlerin dile getirildiği görülür. Hata kaynağı ve nedenine ait bazı kategorilere göre ayrıntılı bilgiler ve ögrretmenlerin ifadelerinden bazı örnekler hata kaynağı kategorileri açısından ayrı başılıklar altında paylaşılmıştır.

\subsubsection{Eğitimcilerden Kaynaklandı̆ğ Öne Sürülen Hatalar ve Nedenleri}

Tablo 5'e göre katılımcı öğretmenler tarafından dile getirilen ve hata kaynağı olarak eğitimci kategorisi altında ele alınan nedenler incelendiğinde, öğretmenlerin çoğunluğunun öğretim ilkelerine uyulmamasını, azımsanmayacak bir bölümünün kavramların ele alınmamasını ve kavramların yanlış kullanılmasını, az bir bölümünün yanlıș materyal tercihi, bilgiyi yanlıș aktarma ve yanlış öğretim yöntemi tercihini dile getirdikleri bunun yanında yalnızca 1 öğretmenin ise 1 durum karşısında neden olarak öğretmenlerin uygun yöntemi bilememesini dile getirdiği görülür.

Hata kaynağı olarak "Eğitimci” kategorisi açısından, Ö3 kodlu öğretmenin "Günlük yaşam deneyimleri şeklinde sunulmadığ için zaman kavramlarını anlayamıyorlar" şeklindeki ifadesi yaşama yakınlık ilkesi ile örtüşmediği için, Ö7 kodlu öğretmenin "Şekilleri ögretirken bir sıra ile ögretmeye çallşlyoruz ama sadece şekilleri öğretmeye çalışlyoruz. Öncesinde altında yatan temel geometrik terimleri vermiyoruz" şeklindeki ifadesi, Ö10 kodlu öğretmenin “Kavramlart çoğu zaman birlikte verdiğimiz için. Bir önceki kavram pekiştirilmeden diğerine geçiyoruz. Sonra da kavramlar karışıyor" şeklindeki ifadesi ile benzer bir şekilde Ö12 kodlu öğretmenin "Kenar ve köşeyi aynı anda vermeye çalışıyoruz. Sonra da çocuklar kenara köşe, köșeye kenar diyorlar. Karıștırıyorlar" şeklindeki ifadesi bilinenden bilinmeyene ilkesi ile uyuşmadığı için Öğretim İlkelerine Uyulmaması kategorisine örnek gösterilebilir.

Kavramın Ele Alınmaması kategorisi açısından ise Ö7 kodlu öğretmenin 10-20 arası sayılar açısından belirttiği "Kapasiteleri var ama biz o kavramlarl vermiyoruz. Ondan hata yapıyorlar" ifadesi, Ö9 kodlu öğretmenin yine ayn kavramlar açısından dile getirdiği "Biz hep 1-10 arası sayllar üzerinde duruyoruz. O yüzden. 10'dan sonrası çoğu zaman ihmal ediliyor" ifadesi, benzer bir şekilde Ö13 kodlu öğretmenin "10-20 arası sayılara çok fazla değinilmiyor. O yüzden çocuklar karıştırabiliyorlar" ifadesi ve Ö15 kodlu öğretmenin tek-çift kavramları açısından belirttiği "tek-çift kavramları ile ilgili çok fazla etkinlik yapılmadiğından kaynaklanıyor" ifadesi, kavramların ele alınmadığını, etkinliklerde yer verilmediğini ortaya koyduğu için örnek gösterilebilir.

Hata kaynağı olarak Eğitimci, Aile ve Toplum kategorilerinde ortak olarak ortaya çıkan Kavramın Yanlış Kullanımı kategorisi için, "Eğitimci" açısından Ö12 kodlu öğretmenin benzer kavramı açısından belirttiği "Ögretmenler benzer ve aynı kavramları birbirleri yerine doğaçlama kullanıyorlar. Çocuklar da bu şekilde kullanıp hata yapıyorlar" ifadesi ve Ö13 kodlu öğretmenin belirttiği "Çocuklara şekilleri ve kenar kavramını öğretirken, kenarlart şekillerin sinırlart olarak öğretiyoruz. Kenar yerine sınır diyoruz. Çember ve dairede de sınır çizmiş oluyoruz. Sonra çocuklar dairenin ve çemberin kenarı olduğunu düşünüyor, kafalarl karışıyor" ifadesi kavramların yanlış kullanıldığını, kavramlar yerine başka kavramların yanlış bir şekilde kullanıldığını ortaya koyduğu için örnek gösterilebilir.

Yanlış Materyal Tercihi açısından ise Ö1 kodlu öğretmenin çocukların önünde-arkasında kavramına ilişkin yaptıkları hataların nedenini "üç boyutlu şeyleri kağıt üzerinde anlamak da anlatmak da zor oluyor" ifadesinde, Ö7 kodlu öğretmenin eşit kavramı açısından belirttiği " $\mathrm{Bazl}$ kitaplarda eşit kavramı hep aynı tür nesneler ile veriliyor. Çocuklar eşit ama farklı tür nesneleri görünce kafaları karışıyor" ifadesi ile yine benzer bir şekilde Ö10 kodlu öğretmenin uzak-yakın kavramı açısından belirttiği "Görsellerde uzak-yakın nesneleri bilemiyorlar. Büyükküçük diyorlar. Çünkü çocuklar resimlerde perspektif amaçll küçük çizilenin uzakta olduğunu anlamıyorlar" ifadesinde basılı kaynakların ilgili kavramların kazandırılması amaciyla kullanımından kaynaklanan hatalardan bahsettikleri görülür.

Ö5 kodlu öğretmenin "Illk öğretirken halka diye öğrettim, kafaları karıştı. Daire-çember-halka kavramları birbirine girdi" ifadesi öğretmenin kavramlar için doğru olmayan ifadeler kullanarak öğretim yaptığını gösterdiği için hata nedeni olarak Bilgiyi Yanlış Aktarma kategorisine örnek gösterilebilir. Yine Ö9 kodlu öğretmenin sağ-sol kavramları açısından belirttiği "Sağ el için yemek yenen el, kalem tuttuğumuz elimiz deniyor ama sol elini kullanan ya da her ikisini de kullanan çocuklar oluyor. Biz bu şekilde 
söyleyince kafaları karlşabiliyor" ifadesi ile Ö13 kodlu öğretmenin sağ-sol kavramları açısından belirttiği "Să̆-sol kavramlarının ögretimi aşamasında kalem tuttuğun el diyoruz bu sıkıntılı. Neye göre să̆-sol açıklamıyoruz" şeklindeki ifadesi, öğretmenlerin sağ-sol kavramları ile ilgili çeşitli durumları göz önüne almadan genelleme yaparak her durum için doğru olmayan ifadeler kullandığını gösterir. Bu açıdan Bilgiyi Yanlış Aktarma kategorisine örnek gösterilebilir.

Ö1 kodlu öğretmenin önce-şimdi-sonra kavramları açısından belirttiği "Çocuklara bu kavramı kağıt üzerinde verdiğimizde zorlanıyorlar. Günlük yaşantılarından örnekler verdiğimiz zaman zorlanmiyorlar. Çocuklara deneyim ve yaşantılardan örnekler verecek yollarla ögrretmek gerek" ifadesi, Ö2 kodlu öğretmenin sağ-sol kavramları açısından ortaya koyduğu "çocuklara sağ ve solu kazandırmak için karşılarına geçip gösterince yönlerde terslik oluyor" ifadesi ile benzer bir şekilde Ö3 kodlu öğretmenin belirttiği "Să̆ ve sol kavramların öğretmek için tam karşılarına geçtiğimde benim sağım solum onlara göre değişebileceğinden dolayı doğru düşünemiyorlar. Bu şekilde ögretmeye çalışmak da yanlış oluyor" ifadesi öğretmenlerin uygulanan öğretim yoluna ve şekline atıfta bulundukları için Yanlış Öğretim Yöntemi Tercihi kategorisi için örnek gösterilebilir.

Eğitimci kategorisi açısından son olarak, yalnızca Ö13 kodlu bir öğretmen tarafindan dile getirilen "Derin-slğ kavramları hem bizim hem çocuklar için çok sıkıntılı bir kavram. Çocuklar derin-sığ yerine az-çok diyorlar. Kavramı anlamıyorlar ama biz de kavramı sunarken nasıl bir yöntem kullanacağımızı bilemiyoruz" ifadesi, kavramın kazanımı sürecinde uygulanabilecek yöntemlerle ilgili bilgi sahibi olunmadığını gösterdiği için Uygun Yöntemi Bilememe kategorisine örnek gösterilebilir.

\subsection{2. Çocuklardan Kaynaklandiğ Hatalar ve Nedenleri}

Tablo 5'e göre öğretmenler tarafından dile getirilen ve hata kaynağı olarak çocuk kategorisi altında ele alınan nedenler incelendiğinde, katılımcı öğretmenlerin tamamının çeşitli durumlar karşısında çocukların bilişsel düzeylerinin yetersizliğini, öğretmenlerin büyük çoğunluğunun çocukların deneyim eksikliğini, yine öğretmenlerin çoğunluğunun çocukların ön koşul öğrenme eksikliğini, öğretmenlerin az bir bölümünün ise çocukların sözcük dağarcıklarının yetersizliğini, motivasyon düzeylerini ve bilgilerini transfer edememelerini, matematiksel kavramları kazanım süreçlerinde yaptıkları hataların nedenleri olarak dile getirdikleri görülür.

Hata kaynağı olarak "Çocuk" kategorisi açısından, hatanın nedeni olarak Bilişsel Düzey Yetersizliğine Ö1 kodlu öğretmenin para kavramına ilişkin ortaya koyduğu "korunumu tam olarak kazanmadıkları için kavramı anlamakta zorlantyorlar" ifadesi, Ö8 kodlu öğretmenin çember kavramı açısından belirttiği "Daire ile çemberi karlştırlyorlar. Farklı şekiller olduğunu algılamakta zorlanıyorlar. Bilişsel olarak yetersiz kalabiliyorlar" ifadesi ve Ö16 kodlu öğretmenin dün-bugün-yarın kavramları açısından belirttiği "Bu kavramlar çocukların seviyelerine göre çok zor kavramlar. Üst kavramlar" ifadesi, öğretmenlerin kavramın kazanımı açısından çocukların olması gerektiği bilişsel düzeyin yetersizliğine vurgu yaptığını gösterdiği için örnek gösterilebilir.

"Deneyim Eksikliği” kategorisine, Ö2 kodlu öğretmenin ortaya koyduğu "Para kavramlarl tekrar edilmiyor ve alışkanlart yok" ifadesi, Ö11 kodlu öğretmenin sabah-öğleakşam kavramları açısından belirttiği "Öğlenci grupta bulunan çocuklar okula öğlen geliyorlar. Çoğu okula geliş saatine yakın kalkıyorlar. Sabahı kaçırıyorlar. Gün öğle olmuş oluyor. Çocuklar sabah ile ögle arasındaki farkı sezemiyorlar. Zaten hava aydinlık, güneşin hareketini gözlemleyemiyorlar. Sicaklık farkını hissedemiyorlar" ifadesi ve Ö14 kodlu öğretmenin "Derin ve siğ olan bir şeyler denemiyorlar ki. Denemeye korkan çocuklar da olabiliyor" ifadesi örnek gösterilebilir. Öğretmenlerin yaptığı açıklamalarda çocukların yaptıkları hataların deneyim eksikliğinden kaynaklandığına vurgu yapmaktadır.

Ön Koşul Öğrenme Eksikliği kategorisi açısından Ö4 kodlu öğretmenin "parçaların birleştirilmesi için gereken geometrik becerilerin gelişmemiş olması" şeklindeki ifadesi, Ö7 kodlu öğretmenin dikdörtgen kavramı açısından belirttiği "Uzun, kısa ve kenar kavramlarl oturmadığ için dikdörtgen ve kareyi birbirine karlştırlyorlar" ifadesi ve Ö10 kodlu öğretmenin "Taraf kelimesini bilmiyorlar. O yüzden să̆ında-solunda kavramlarını karıştırıyorlar" şeklindeki ifadesi, öğretmenlerin ilgili kavramların kazanılması açısından daha önceden kazanılmış olmasını gerekli gördükleri kavramlar vurgu yaptıkları için örnek gösterilebilir.

Sözcük Dağarcı̆̆ının Yetersizliği kategorisi açısından Ö3 kodlu öğretmenin önce-şimdi-sonra kavramları açısından belirttiği "Kelimelerin anlamı ile hangi zaman sırasını belirttiğini bilmiyorlar" ifadesi ile Ö2 kodlu öğretmenin sabah-öğle-akşam kavramları açısından belirttiği "kelimelerin anlamlarını bilmiyorlar" ifadesi örnek gösterilebilir. Bu ifadelerde öğretmenlerin çocukların sahip olmaları gereken kelime anlam bilgisi ve sözcük dağarcığına vurgu yaptıklarını söylenebilir.

Motivasyon Düzeyi kategorisi açısından ise Ö5 kodlu öğretmenin belirttiği “dikkatlerini yoğunlaştıramadıkları için şekillerin kenarlarında hata yapıyorlar" ifadesi ve Ö12 kodlu öğretmenin ilk-orta-son kavramları açısından belirttiği “"3'lü dizilerde sorun yok. Ama sayl artınca nesne dizesinden ortada olanı bulmakta zorlanıyorlar. Tek sayıl dizilerde yanlardan birer nesne çıkarsa ortada tek bir nesne kalacağını görebilirler. Buna dikkat etmiyorlar. Aslında dikkat etseler bulurlar" ifadesi, öğretmenlerin çocukların bazı noktalara dikkat etmedikleri için hata yaptıklarını vurguladıkları için örnek gösterilebilir.

Çocuklardan kaynaklanan hatalar ve nedenleri açısından son kategori olarak Bilgiyi Transfer Edememe açısından Ö10 kodlu öğretmenin ince-kalın kavramları açısından belirttiği "Çocuklar önce büyük küçük kavramların ögreniyorlar. Ince ve kalın cisimler verdiğimizde onlarl da büyük veya küçük zannediyorlar. Önce büyük ve küçük 
kavramlarını öğrendikleri için akılları oraya gidiyor" şeklindeki ifadesi, çocukların ön öğrenmelerinin yeni bilgiye transferi konusunda bir ket oluşturduğu ve Ö14 kodlu öğretmenin sıra sayısı kavramı açısından belirttiği "Sayılart saymakta sikntı olmuyor. Sayı kavramların iyi bilseler de dizilerde sayıları siralamaya göre anlamlandırmakta zorlanıyorlar" ifadesi, çocukların nesne dizisinde sayılan nesnenin sayısının sıralamayı ifade etmesi açısından sayı bilgisini sıra bilgisine transfer emekte zorlandıklarını gösterir. $\mathrm{Bu}$ açıdan ilgili öğretmenlerin ifadeleri Bilgiyi Transfer Etme kategorisinde değerlendirilebilir.

\subsubsection{Kavramın Doğasından Kaynaklandĭ̆ Öne Sürülen Hatalar ve Nedenleri}

Yine Tablo 5'e göre hata kaynağı olarak kavramın doğası kategorisi altında ele alınan nedenler incelendiğinde, katılımc1 öğretmenlerin büyük çoğunluğunun kavramın soyutluğunu, çoğunluğunun kavramların diğer kavramlara benzerliğini ve kavramların güncel olmayışını ve katılımeı öğretmenlerin yarısının ise kavramın zorluğunu bir neden olarak dile getirdiği görülür.

"Kavramın Doğası" kategorisi altında Kavramın Soyutluğu açısından Ö6 kodlu öğretmenin zaman kavramları için ortaya koyduğu "Kavramlar soyut kallyor" ifadesi, Ö8 kodlu öğretmenin dün-bugün-yarın kavramları için belirttiği "Çocuklar yarın kavramını gün içerisinde çok karıştırlyorlar. Yarını, bugün için yaşayamadıkları için onlara soyut kallyor. Karıştırlyorlar" ifadesi ve Ö16 kodlu öğretmenin sağ-sol kavramları için belirttiği "Yaş grubu için henüz soyut kavramlar olduğu için karıştırıyorlar" ifadesi, öğretmenlerin ilgili kavramların soyut kalması özelliğine vurgu yaptıkları için örnek gösterilebilir.

Diğer Kavramlara Benzerliği kategorisi açısından ise Ö5 kodlu öğretmenin "dikdörtgen şekli kareye benzediği için kavramlar oturmuyor" ifadesi, Ö9 ve Ö11 kodlu öğretmenlerin "Çember ve daire birbirine benzediği için çocuklar karış̧trılyorlar" ifadeleri ile Ö15 kodlu öğretmenin "çember-daire-elips birbirine benzer kavramlar olduklart için çocuklar birbirine karıştırıyorlar" ifadesi, öğretmenler tarafindan kavramların benzer özellikler taşıdığ 1 vurgulandığından dolayı örnek gösterilebilir.

Kavramın Güncel Olmaması kategorisine örnek olarak, Ö4 kodlu öğretmenin "Elips çok sik kullanılan bir kavram olmadı̆̆ için çocuklar öğrenmekte zorluklar yaşıyorlar" ifadesi, Ö7 kodlu öğretmenin kalabalık-tenha kavramları açısından belirttiği "Kalabalık kullanılsa da tenha çok kullanılmiyor. Kavramlar günlük yaşamda pek kullanılan kavramlar değil" ifadesi ve Ö12 kodlu öğretmenin derinsığ kavramları açısından dile getirdiği "Bu kavramlar çok kullanılmıyor. O yüzden karıştırıyorlar" gösterilebilir. Burada öğretmenlerin ilgili kavramların günlük yaşamda çok fazla kullanılmadığına ve güncel kavramlar olmadığına vurgu yaptıkları söylenebilir.

Hata kaynağı olarak kavramın doğası açısından son olarak Kavramın Zorluğu kategorisi için ise Ö2 kodlu öğretmenin ortaya koymuş olduğu "Zaman kavramları çocuklar için zor kavramlardır. Algilamakta zorlaniyorlar" ifadesi, Ö11 kodlu öğretmenin tek-çift kavramları açısından dile getirdiği "Soyut kaldığı için algılaması zor geliyor. Okul öncesi düzey için çok zor kavramlar" ifadesi, Ö13 kodlu öğretmenin sağ-sol kavramları açısından belirttiği "Biraz zor okul öncesi için. Öğretilmese daha iyi" ifadesi ve Ö14 kodlu öğretmenin farklı-benzer kavramları açısından belirttiği "Aynı tür nesnelerde farkı bulmalar ve farkl nesnelerde benzer özellikleri bulmalarl onlar için zor oluyor" ifadesi örnek gösterilebilir. Burada öğretmenlerin ilgili kavramlar için belirttikleri açıklamalarda çeşitli sebeplerden dolayı kavramların kazanımının çocuklar açısından zor olduğunun vurgulandığı görülür.

\subsubsection{Ailelerden Kaynaklandiğg Öne Sürülen Hatalar ve Nedenleri}

Tablo 5 incelendiğinde hata kaynağı olarak aile kategorisinde neden olarak yalnızca kavramın yanlış kullanımı alt kategorisinin ortaya çıtı̆ğı görülür. Katılımcı öğretmenlerin azımsanmayacak bir bölümünün, çocukların matematiksel kavramları kazanım sürecinde yaptığı hatalar açısından aileden kaynaklı bir neden olarak kavramın yanlış kullanılmasını dile getirdikleri görülür.

Hata kaynağı olarak Aile kategorisi açısından Ö1 kodlu öğretmenin içinde-dışında kavramı açısından ortaya koyduğu, "Aileler kavramları uygun bir şekilde kullanmıyorlar" ifadesi ve Ö7 kodlu öğretmenin geniş-dar kavramları açısından belirttiği "Anne-babalar da geniş-dar kavramlart yerine ince-kalın kavramlarin kullanabiliyor. Çocuklar da geniş-dar kavramlarını ince ve kalın ile karıştırabiliyorlar" ifadesi ve Ö9 kodlu öğretmenin kenar kavramı açısından belirttiği "Evde aileler de yanllş kullanabiliyor. Bu yüzden çocuklar da kenar ve kösseyi karıştırabiliyor" ifadesi ile Ö12 kodlu öğretmenin çember kavramı açısından belirttiği "Bazen aileler de çember şekli için daire diyorlar. Aileler de böyle dediği için çocuklar karıștırıyor" ş̧eklindeki ifadeleri Kavramın Yanlış Kullanımı kategorisine örnek gösterilebilir. Burada öğretmenlerin ifadelerinde ailelerin kavramları yanlış şekillerde kullandığına vurgu yaptığı söylenebilir.

\subsubsection{Toplumdan Kaynaklandığ Öne Sürülen Hatalar ve Nedenleri}

Tablo 5'e göre, hata kaynağı olarak ele alınabilecek son kategori olan toplum kategorisi açısından kavramın yanlış kullanımı şeklinde yalnızca 1 alt kategorinin oluştuğu ve katılımcı öğretmenlerden yalnızca 1'inin çocukların matematiksel kavramları kazanım süreçlerinde toplumdan kaynaklı nedenlerden dolayı hata yaptığı ve neden olarak ise kavramların toplum tarafından yanlış kullanıldığını ileri sürdüğü görülür.

Ele alacağımız son hata kaynağı olarak Toplumdan Kaynaklanan hatalar şeklinde oluşan tek kategori açısından yalnızca Ö9 kodlu öğretmenin dile getirdiği Kavramın Yanlış Kullanılması için belirttiği "Halk dilinde daire yerine yuvarlak denmesi, çocukların daire şekli için yanlış isimler kullanmalarina sebep oluyor" ifadesi örnek gösterilebilir. Burada ilgili öğretmenin toplum tarafından 
kavramın yanlış bir şekilde kullanıldığına vurgu yaptı̆̆ söylenebilir.

\subsection{Hataların Giderilmesine Yönelik Stratejilere İlişkin Bulgular}

Öğretmenlerin, çocuklar tarafindan kazanım süreçlerinde sıklıkla ortaya koyulan hataların giderilmesine yönelik uyguladıkları stratejiler, matematiksel kavramların doğasının, öğrenme süreç ve şekillerinin birbirinden farklı olabilmesi durumlarından dolayı her bir matematiksel kavram kategorisi için ayrı tablolar halinde düzenlenmiş̧ir. Ortaya çıkan bulgular her bir kavram kategorisi için ayrı alt başlıklar altında ele alınmıştır.

\subsection{1 Şekil Kavramlarına Ilişkin Hataların Giderilmesine Yönelik Stratejiler}

Öğretmenlerin şekil kavramlarına ilişkin hataların giderilmesine yönelik uyguladıkları stratejilere ait bulgular Tablo 6'da sunulmuştur.

Tablo 6. Şekil Kavramlarına İlişkin Hataların Giderilmesine Yönelik Stratejiler

\begin{tabular}{ll}
\hline Kavram-Strateji & Katılımcılar \\
\hline Eğitsel Oyun & Ö7,Ö8,Ö10,Ö11,Ö12,Ö13,Ö14,Ö15 \\
Görselleştirme & Ö7,Ö10,Ö12,Ö14 \\
Sunuş Yoluyla Öğrenme & Ö9,Ö10,Ö11,Ö12 \\
Somut Yaşant1 Sunma & Ö5,Ö10,Ö11,Ö12 \\
Düz Anlatım & Ö5,Ö7,Ö8,Ö14 \\
Buluş Yoluyla Öğrenme & Ö6,Ö9,Ö10 \\
Çalışma Yaprağ1 & Ö6,Ö9,Ö11 \\
Sanat Etkinliği & Ö4,Ö9 \\
Tartı̧ma & Ö5 \\
Analoji & Ö5 \\
\hline
\end{tabular}

Tablo 6 incelendiğinde çocukların şekil kavramlarını kazanım süreçlerinde yaptıkları hataların giderilmesi açısından katılımcı öğretmenlerin yarısının eğitsel oyunu, azımsanmayacak bir bölümün görselleştirme, sunuş yoluyla öğrenme, somut yaşantı sunma ve düz anlatımı, az bir bölümünün buluş yoluyla öğrenme, çalışma yaprağ ve sanat etkinliğini, son olarak bir öğretmenin iki farklı durum açısından tartışma ve analojiyi birer strateji olarak kullandığı görülür.

Öğretmenlerin şekil kavramlarının kazanımı süreçlerinde çocuklar tarafindan yapılan hataların giderilmesi açısından uyguladıkları stratejilerden Eğitsel Oyun, Görselleştirme, Analoji, Somut Yaşantı Sunma, Buluş Yoluyla Öğrenme, Çalışma Yaprağı ve Sanat Etkinliklerinin okul öncesi dönemdeki çocukların gelişimsel özellikleri ve şekil kavramlarının doğası açısından uygun stratejiler olduğu kabul edilebilir. Bunun yanında şekillerin farklı özellikleri ve geometrik ilişkileri düşünüldüğünde, Tartışma, Düz Anlatım ve Sunuş Yoluyla Öğrenmenin ise zaten var olan hataların giderilmesinde etkili stratejiler olmayacağ 1 düşünülebilir. Buna rağmen öğretmenlerin ş̧ekil kavramlarına ilişkin ortaya koyulan hata durumlarının büyük çoğunluğunda uygun stratejiler kullandıkları söylenebilir.

\subsubsection{Boyut Kavramlarına Illişkin Hataların Giderilmesine Yönelik Stratejiler}

Öğretmenlerin boyut kavramlarına ilişkin hataların giderilmesine yönelik uyguladıkları stratejilere ait bulgular Tablo 7'de sunulmuş̧ur.

Tablo 7. Boyut Kavramlarına İlişkin Hataların Giderilmesine Yönelik Stratejiler

\begin{tabular}{|c|c|c|}
\hline \multicolumn{2}{|c|}{ Kavram-Strateji } & \multirow{2}{*}{$\begin{array}{l}\text { Katılımcılar } \\
\ddot{O} 9\end{array}$} \\
\hline & Eğitsel Oyun & \\
\hline B & Sunuş Yoluyla Öğrenme & Ö7 \\
\hline & Dolaylı Ögretim & Ö10 \\
\hline
\end{tabular}

Öğretmen görüşleri açısından çocuklar tarafindan en az hata yapılan kavram kategorisi olarak boyut kavramlarına ilişkin hataların giderilmesine yönelik stratejilerin sunulduğu Tablo 7 incelendiğinde yalnızca 1'er öğretmenin eğitsel oyunu, sunuş yoluyla öğrenmeyi ve dolaylı öğretimi birer strateji olarak kullandığı görülür.

Genel olarak çocukların gelişimsel özellikleri ve boyut kavramlarının doğası düşünüldüğünde, Eğitsel Oyun ve Dolaylı Öğretimin hataların giderilmesinde etkili stratejiler olarak kullanılabileceği, buna karşın Sunuş Yoluyla Öğrenmenin etkili bir strateji olarak kullanılamayacağ 1 kabul edilebilir. $\mathrm{Bu}$ açıdan öğretmenlerin boyut kavramlarına ilişkin hataların giderilmesinde genel olarak uygun stratejiler kullandıkları söylenebilir.

\subsubsection{Miktar Kavramlarına İlişkin Hataların Giderilmesine Yönelik Stratejiler}

Öğretmenlerin miktar kavramlarına ilişkin hataların giderilmesine yönelik uyguladıkları stratejilere ait bulgular Tablo 8'de sunulmuştur.

Tablo 8. Miktar Kavramlarına İlişkin Hataların Giderilmesine Yönelik Stratejiler

\begin{tabular}{ll}
\hline Kavram - Strateji & Katılımcılar \\
\hline Eğitsel Oyun & Ö3,Ö4,Ö7,Ö13 \\
Somut Yaşantı Sunma & Ö5,Ö7,Ö11 \\
Eğitici Materyal Sunma & Ö4,Ö13 \\
Tekrar & Ö4,Ö15 \\
Aile Katılımı Etkinlikleri & Ö1,Ö11 \\
Düz Anlatım & Ö7,Ö15 \\
Buluş Yoluyla Öğrenme & Ö7,Ö12 \\
Cesaretlendirme & Ö4 \\
Günlük Yaşamdan Örnekler Sunma & Ö7 \\
Sunuş Yoluyla Öğrenme & Ö10 \\
Demonstrasyon & Ö6 \\
Çalışma Yaprağ1 & Ö2 \\
Aktif Öğrenme & Ö14 \\
\hline
\end{tabular}

Tablo 8 incelendiğinde öğretmenlerin azımsanmayacak bir bölümünün, çocukların miktar kavramlarını kazanım sürecinde yaptıkları hataların giderilmesinde eğitsel oyunu, az bir bölümünün somut yaşantı sunmayı, eğitici materyal sunmayı, tekrarı, aile katılımını, düz anlatımı ve buluş yoluyla öğrenmeyi, bunun yanında 1'er öğretmenin ise cesaretlendirmeyi, günlük yaşamdan örnekler sunmayı, sunuş yoluyla öğrenmeyi, demonstrasyonu, çalışma yaprağını ve aktif öğrenmeyi birer strateji olarak uyguladıkları görülür.

Çocukların gelişimsel özellikleri ve miktar kavramlarının doğası açısından öğretmenlerin uyguladıkları Eğitsel Oyun, 
Eğitici Materyal Sunma, Somut Yaşantı Sunma, Aile Katılımı Etkinlikleri, Buluş Yoluyla Öğrenme, Cesaretlendirme, Günlük Yaşamdan Örnekler Sunma ve Aktif Öğrenmenin uygun stratejiler olduğu kabul edilebilir. Bunun yanında Tekrar, Düz Anlatım, Sunuş Yoluyla Öğrenme ve Demonstrasyonun uygun stratejiler olmadığı söylenebilir. Sonuç olarak öğretmenlerin miktar kavramlarına ilişkin ortaya koyulan hata durumlarının çoğunluğunda uygun stratejiler kullandıkları söylenebilir.

\subsubsection{Yer-Yön Kavramlarına Ilişskin Hataların Giderilmesine Yönelik Stratejiler}

Öğretmenlerin yer-yön kavramlarına ilişkin hataların giderilmesine yönelik uyguladıkları stratejilere ait bulgular Tablo 9'da sunulmuştur.

Tablo 9. Yer-Yön Kavramlarına İlişkin Hataların Giderilmesine Yönelik Stratejiler

\begin{tabular}{ll}
\hline Kavram - Strateji & Katılımcılar \\
\hline Eğitsel Oyun & Ö3,Ö10,Ö12,Ö14 \\
Sunuş Yoluyla Öğrenme & Ö9,Ö10 \\
Müzik Yoluyla Öğretim & Ö1,Ö14 \\
Sanat Etkinlikleri & Ö5 \\
$: \quad$ Ö6 \\
Demonstrasyon & Ö2 \\
Buluş Yoluyla Öğrenme & Ö13 \\
Drama & Ö12 \\
Somut Yaşantı Sunma & Ö15 \\
Dolaylı Öğretim & Ö10 \\
Herhangi Bir Strateji Uygulayamama & Ö16 \\
\hline
\end{tabular}

Tablo 9 incelendiğinde çocukların yer-yön kavramlarının kazanımı sürecinde yaptıkları hataların giderilmesi açısından öğretmenlerin azımsanmayacak bir bölümünün eğitsel oyunu, az bir bölümünün sunuş yoluyla öğrenme ve müzik yoluyla öğrenmeyi, bunun yanında 1'er öğretmenin ise sanat etkinliğini, demonstrasyonu, buluş yoluyla öğrenmeyi, dramayı, somut yaşantı sunmay1, görselleştirmeyi, dolaylı öğretimi birer strateji olarak kullandıkları görülür. Aynı zamanda 1 öğretmenin ise çocukların yer-yön kavramlarını kazanım sürecinde ortaya koydukları hataların giderilmesinde herhangi bir strateji uygulayamadığı görülür.

Öğretmenlerin uyguladığı stratejilerin uygunluğu açısından, çocukların gelişimsel özellikleri ve yer-yön kavramlarının doğası düşünüldüğünde öğretmenlerin kullandıkları Eğitsel Oyun, Müzik Yoluyla Öğretim, Sanat Etkinlikleri, Buluş yoluyla Öğrenme, Drama, Somut Yaşantı Sunma ve Görselleştirmenin uygun stratejiler olduğu kabul edilebilir. Bunun yanında Sunuş Yoluyla Öğrenme, Demonstrasyon ve Dolaylı Öğretimin uygun stratejiler olmadığı düşünülebilir. Sonuç olarak öğretmenlerin, yer-yön kavramlarına ilişkin ortaya koyulan hata durumlarının çoğunluğunda uygun stratejiler kullandıkları söylenebilir.

\subsubsection{Sayı Kavramlarına İlişkin Hataların Giderilmesine Yönelik Stratejiler}

Öğretmenlerin, çocukların sayı kavramlarının kazanımı sürecinde ortaya koyduğu hataların giderilmesine ilişkin uyguladıkları stratejilere ait bulgular Tablo 10'da sunulmuştur.
Tablo 10. Sayı Kavramlarına İlişkin Hataların Giderilmesine Yönelik Stratejiler

\begin{tabular}{ll}
\hline Kavram - Strateji & Kattımcılar \\
\hline Sunuş Yoluyla Öğrenme & Ö7,Ö8,Ö10,Ö13 \\
Düz Anlatım & Ö3,Ö7,Ö8,Ö15 \\
Eğitsel Oyun & Ö10,Ö12 \\
Aktif Öğrenme & Ö9,Ö11 \\
Hikayeleştirme & Ö3 \\
Görselleştirme & Ö3 \\
B̈. Ouluş Yoluyla Öğrenme & Ö1 \\
Drama & Ö3 \\
Demonstrasyon & Ö14 \\
Deney & Ö10 \\
Analoji & Ö5 \\
Herhangi Bir Strateji Uygulayamama & Ö14 \\
\hline
\end{tabular}

Tablo 10 incelendiğinde, çocukların sayı kavramlarını kazanım süreçlerinde ortaya koydukları hataların giderilmesinde katılımcı öğretmenlerin azımsanmayacak bir bölümünün sunuş yoluyla öğrenmeyi ve düz anlatımı, az bir bölümünün eğitsel oyunu ve aktif öğrenmeyi, bunun yanında 1'er öğretmenin ise hikayeleştirme, görselleştirme, buluş yoluyla öğrenme, drama, demonstrasyon, deney ve analojiyi birer strateji olarak kullandıkları görülür. Ek olarak 1 öğretmenin ise çocukların sayı kavramlarının kazanımı sürecinde ortaya koydukları hataların giderilmesi açısından herhangi bir strateji uygulayamadığı görülür.

Uygulanan yöntem veya stratejilerin uygunluğu açısından, çocukların gelişimsel özellikleri ve sayı kavramlarının doğası düşünüldüğünde, öğretmenlerin hataların giderilmesine yönelik uyguladıkları Eğitsel Oyun, Aktif Öğrenme, Hikayeleştirme, Görselleştirme, Buluş Yoluyla Öğrenme ve Dramanın uygun stratejiler olduğu kabul edilebilir. Bunun yanında öğretmenler tarafından uygulanan Sunuş Yoluyla Öğrenme, Düz Anlatım, Demonstrasyon, Deney ve Analojinin uygun stratejiler olmadığ 1 kabul edilebilir. Sonuç olarak öğretmenlerin sayı kavramlarına ilişkin ortaya koyulan hata durumlarının çoğunluğunda uygun stratejiler kullandıkları söylenebilir.

\subsubsection{Zit Kavramlara İlişkin Hatalartn Giderilmesine Yönelik Stratejiler}

Matematiksel kavramlar altında ele alınan zıt kavramlara ilişkin hataların giderilmesine yönelik uygulanan stratejiler ve dağılımları Tablo 11 'da sunulmuştur.

Tablo 11 Zit Kavramlara İlişkin Hataların Giderilmesine Yönelik Stratejiler

\begin{tabular}{ll}
\hline Kavram - Strateji & Katılımcılar \\
\hline Herhangi Bir Strateji Uygulayamama & Ö1,Ö6,Ö14 \\
Sunuş Yoluyla Öğrenme & Ö2,Ö14 \\
Görselleştirme & Ö4,Ö12 \\
Eğitsel Oyun & Ö6 \\
Günlük Yaşamdan Örnekler Sunma & Ö7 \\
Buluş Yoluyla Öğrenme & Ö13 \\
Çalışma Yaprağ1 & Ö2 \\
Deney & Ö10 \\
Dolaylı Öğretim & Ö6 \\
Somut Yaşantı Sunma & Ö13 \\
\hline
\end{tabular}

Tablo 11 incelendiğinde, zıt kavramlara ilişkin yapılan hataların giderilmesi açısından, katılımcı ögretmenlerin az bir bölümünün herhangi bir strateji uygulayamadığı görülse de bu kavram kategorisinde en fazla öğretmen tarafindan dile getirilen alt kategori olduğu görülür. Bunun yanında öğretmenlerin az bir bölümünün sunuş yoluyla öğrenmeyi ve görselleştirmeyi, 1'er öğretmenin ise eğitsel oyunu, günlük yaşamdan örnekler sunmayı, 
buluş yoluyla öğrenmeyi, çalışma yaprağını, deneyi, dolaylı öğretimi ve somut yaşantı sunmayı birer strateji olarak uyguladıkları görülür.

Çocukların gelişimsel özellikleri ve zıt kavramların doğası düşünüldüğünde öğretmenlerin uyguladıkları Görselleştirme, Eğitsel Oyun, Günlük Yaşamdan Örnekler Sunma, Buluş Yoluyla Öğrenme, Çalışma Yaprağı, Deney ve Somut Yaşantı Sunma hataların giderilmesine yönelik uygun stratejiler olarak kabul edilebilir. Bunun yanında Sunuş Yoluyla Öğrenme ve Dolaylı Öğretimin uygun stratejiler olmadığı kabul edilebilir. Sonuç olarak öğretmenlerin çocuklar tarafindan zit kavramlara ilişkin ortaya koyulan hata durumlarının çoğunluğunda uygun stratejiler kullandıkları söylenebilir.

\subsubsection{Zaman Kavramlarına İlişkin Hataların Giderilmesine Yönelik Stratejiler}

Son olarak öğretmenlerin, çocuklar tarafından zaman kavramına ilişkin yapılan hataların giderilmesine yönelik uyguladıkları stratejiler ve dağılımları Tablo 12'de sunulmuştur.

Tablo 12 Zaman Kavramlarına İlişkin Hataların Giderilmesine Yönelik Stratejiler

\begin{tabular}{|c|c|c|}
\hline \multicolumn{2}{|c|}{ Kavram - Strateji } & Katılımeı \\
\hline \multirow{10}{*}{$\begin{array}{l}\text { ज्ञ } \\
\text { ज્ } \\
\text { స్ }\end{array}$} & Günlük Yaşamdan Örnekler Sunma & Ö1,Ö3,Ö7,Ö10,Ö11,Ö13 \\
\hline & Sunuş Yoluyla Öğrenme & Ö5,Ö10,Ö11,Ö14 \\
\hline & Hikayeleştirme & Ö3,Ö6,Ö8 \\
\hline & Görselleştirme & Ö2,Ö12 \\
\hline & Drama & Ö1,Ö13, \\
\hline & Düz Anlatım & Ö6 \\
\hline & Sanat Etkinliği & Ö7 \\
\hline & Eğitsel Oyun & Ö9 \\
\hline & Dolaylı Öğretim & Ö3 \\
\hline & Herhangi Bir Strateji Uygulayamama & Ö16 \\
\hline
\end{tabular}

Tablo 12 incelendiğinde öğretmenlerin azımsanmayacak bir bölümünün günlük yaşamdan örnekler sunma ve sunuş yoluyla öğrenmeyi, az bir bölümünün hikayeleştirme, görselleştirme ve dramay1, 1'er öğretmenin ise düz anlatımı, sanat etkinliğini, eğitsel oyunu ve dolaylı öğretimi birer strateji olarak uyguladıkları görülür. Bunun yanında 1 öğretmenin ise zaman kavramlarına ilişkin ortaya koyulan hataların giderilmesinde herhangi bir strateji uygulayamadığı görülür.

Yine çocukların gelişimsel özellikleri ve zaman kavramlarının doğası dikkate alındığında öğretmenler tarafindan uygulanan Günlük Yaşamdan Örnekler Sunma, Hikayeleştirme, Görselleştirme, Drama ve Eğitsel Oyunun zaman kavramlarına ilişkin hataların giderilmesinde uygun stratejiler olduğu kabul edilebilir. Bunun yanında öğretmenler tarafından uygulanan Sunuş Yoluyla Öğrenme, Düz Anlatım ve Sanat Etkinliğinin uygun stratejiler olmadığı kabul edilebilir. Genel olarak bakıldığında ise öğretmenlerin çocuklar tarafından zaman kavramlarına ilişkin ortaya koyulan hata durumlarının çoğunluğunda uygun stratejiler kullandıkları söylenebilir.

\subsubsection{Tüm Matematiksel Kavramlara Ilișsin Hataların Giderilmesine Yönelik Stratejiler}

Genel olarak tüm matematiksel kavramlara ilişkin hataların giderilmesine yönelik uygulanan stratejilere ait bulgular Tablo 13'te sunulmuştur.
Tablo 13 Tüm Matematiksel Kavramlara İlișkin Hataların Giderilmesine Yönelik Stratejiler

\begin{tabular}{|c|c|c|}
\hline \multicolumn{2}{|r|}{ Kavram - Strateji } & Katılımcılar \\
\hline \multirow{23}{*}{ 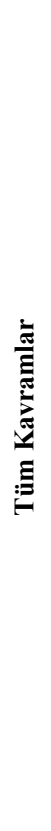 } & Eğitsel Oyun & $\begin{array}{l}\text { Ö3,Ö4,Ö6,Ö7,Ö8,Ö9,Ö10,Ö11,Ö12 } \\
\text { Ö13,Ö14,Ö15 }\end{array}$ \\
\hline & Sunuş Yoluyla Öğrenme & Ö2,Ö5,Ö7,Ö8,Ö9,Ö10,Ö11,Ö12,Ö1 \\
\hline & Görsellestirme & Ö2,Ö3,Ö4,Ö7,Ö10,Ö12,Ö14,Ö15 \\
\hline & Düz Anlatım & Ö3,Ö5,Ö6,Ö7,Ö8,Ö14,Ö15 \\
\hline & Buluş Yoluyla Öğrenme & Ö1,Ö2,Ö6,Ö7,Ö9,Ö10,Ö12 \\
\hline & Günlük Yaşamdan Örnekler & Ö1,Ö3,Ö7,Ö10,Ö11,Ö13 \\
\hline & Somut Yaşantı Sunma & Ö5,Ö7,Ö10,Ö11,Ö12,Ö13 \\
\hline & Çalışma Yaprağı & Ö2,Ö6,Ö9,Ö11 \\
\hline & Sanat Etkinliği & Ö4,Ö5,Ö7,Ö9 \\
\hline & Herhangi Bir Strateji Uyglm. & Ö1,Ö6,Ö14,Ö16 \\
\hline & Drama & Ö1,Ö3,Ö13 \\
\hline & Hikayeleştirme & Ö3,Ö6,Ö8 \\
\hline & Aktif Öğrenme & Ö9,Ö11,Ö14 \\
\hline & Dolaylı Öğretim & Ö3,Ö6,Ö10 \\
\hline & Eğitici Materyal Sunma & Ö4,Ö13 \\
\hline & Demonstrasyon & Ö6,Ö14 \\
\hline & Müzik Yoluyla Öğretim & Ö1,Ö14 \\
\hline & Aile Katılımı & Ö1,Ö11 \\
\hline & Tekrar & Ö4,Ö15 \\
\hline & Analoji & Ö5 \\
\hline & Deney & Ö10 \\
\hline & Cesaretlendirme & Ö4 \\
\hline & Tartışma & Ö5 \\
\hline
\end{tabular}

Tablo 13 incelendiğinde tüm matematiksel kavramlara ilişkin ortaya koyulan hataların giderilmesine yönelik olarak öğretmenlerin büyük çoğunluğunun eğitsel oyunu, öğretmenlerin çoğunluğunun sunuş yoluyla öğrenmeyi, öğretmenlerin yarısının görselleştirmeyi, öğretmenlerin azımsanmayacak bir bölümünün düz anlatım, buluş yoluyla öğrenme, günlük yaşamdan örnekler sunma, somut yaşantı sunma, çalışma yapağı ve sanat etkinliğini birer strateji olarak kullandığ́ ve bunun yanında öğretmenlerin azımsanmayacak bir bölümünün çocukların genel olarak matematiksel kavramları kazanım sürecinde ortaya koydukları hataların giderilmesinde herhangi bir strateji uygulayamadıkları görülür. Yine öğretmenlerin az bir bölümünün drama, hikayeleştirme, aktif öğrenme, dolaylı öğretim, eğitici materyal sunma, demonstrasyon, müzik yoluyla öğretim, aile katılımı ve tekrarı kullandıkları, 1'er öğretmenin ise analoji, deney, cesaretlendirme ve tartı̧̧mayı birer strateji olarak kullandıkları görülür.

Öğretmenlerin stratejilere ilişkin ifadelerinden örnekler vermek gerekirse; Eğitsel Oyun kategorisi açısından Ö7 kodlu öğretmenin tek-çift kavramları için belirttiği "Çocukların çoraplarını çıkarmalarını istiyorum. Gözleri kapalı olduğunda çoraplarını farklı yerlere saklyyorum. Tekini bulduklarında ve çiftini bulduklarında söylemelerini istiyorum. Bu şekilde oyun oynatıyorum" ifadesi; Sunuş Yoluyla Öğrenme kategorisi açısından Ö13 kodlu öğretmenin belirttiği "İki basamakll sayllarl ögretmek için beyaz tahtaya alt alta dokuz tane 1 yazlyorum ve 1'lerin sağında kalacak şekilde çizgi çekiyorum. Birden dokuza kadar her seferinde rakamları çizginin sağına yerleştirip çocuklara on dedikten sonra yerleştirdiğimiz sayıy söylememiz gerektiğini göstererek anlatyorum" ifadesi; Görselleştirme kategorisi açısından Ö4 kodlu öğretmenin derin-sı ğ kavramları için belirttiği "Tahtaya derin ve sĭ̆ ile ilgili resim çiziyorum" ifadesi; Düz Anlatım kategorisi için Ö9 kodlu öğretmenin belirttiği "Daire ve çemberi birbirine karıştırdıklarında daire de çember de yuvarlaktır ama 
çemberin içi boş dairenin içi dolu diye anlatıyorum" ifadesi; Somut Yaşantı Sunma kategorisi açısından Ö5 kodlu öğretmenin, çocukların kenar kavramına ilişkin yaptıkları hataların giderilmesi açısından ortaya koyduğu "Şekillere dokunmalarını sağlayarak saydırıyorum" ifadesi; Buluş Yoluyla Öğrenme kategorisi için Ö12 kodlu öğretmenin belirttiği "Çocukların birebir deneyerek öğrenmelerini sağllyorum. Çeşitli materyaller koyarak ağırlıklarını hissetmelerini, sonrasında tartıp karşılaştırmalarını sağlıyorum. Hangisi ă̆ır çıktı? Hangisinin rakamı yüksek çıktı? Hissettiğinle aynı mıydı? Şekkinde sorular sorarak destekliyorum" ifadesi; Çalışma Yaprağ1 kategorisi için Ö2 kodlu öğretmenin belirttiği "Üzerinde çeşitli miktarlarda paralar ve nesnelerin karşılaştırılması gereken etkinlik sayfaları dağıtıyorum" ifadesi; Günlük Yaşamdan Örnekler kategorisi açısından Ö2 kodlu öğretmenin ortaya koyduğu "Günlük yaşamdan benzer nesnelerle ilgili sohbet yaptırlyorum" ifadesi; Drama kategorisi için Ö13 kodlu öğretmenin belirttiği "Çocuklarl arka arkaya diziyorum. En başa ben sırtım dönük geçiyorum. Şimdi uçak oluyoruz deyip hepimiz ellerimizi iki yana açıyoruz. Uçak uçuyor. Şuraya geldi. Kuvvetli rüzgarlar var, sağa yatıyor, sola yatıyor gibi komutlar veriyorum" ifadesi; Eğitici Materyal Sunma kategorisi açısından yine Ö4 kodlu öğretmenin ortaya koyduğu "Parça-bütün kavramına yönelik hataların giderilmesi için puzzle oyunundan yararlanıyorum" ifadesi; Hikayeleştirme kategorisi için Ö3 kodlu öğretenin 1-10 arası sayılara ilişkin belirttiği "Sayıları hikayeleştiriyorum. Beşin kocaman bir göbeği varmış gibi hikaye oluşturup sayıları tanıtıyorum" ifadesi; Sanat Etkinliği kategorisi için Ö9 kodlu öğretmenin kenar kavramı açısından belirttiği "Çocuklara çerçeve şeklinde şekilleri kestiriyorum. Şimdi kenarlarına çiçekler çizelim, düğmeler yapıştıralım şeklinde yönergeler vererek sanat çalışmaları yaptırıyorum" ifadesi; "Aktif Öğrenme" kategorisi için Ö9 kodlu öğretmenin belirttiği "Miknatıslı tahta kullanıyorum. 0'dan 9'a kadar rakamların olduğu kartları koyuyorum. Çocuklardan kağıtlarda yazılı olan iki basamaklı sayıları kartları birleştirerek bizzat oluşturmalarını, kağıtlara aynen yazmalarını ve sayıları söylemelerini istiyorum. Bu şekilde kendi kendilerine yapmalarını sağlıyorum" ifadesi; "Demonstrasyon" kategorisi için Ö14 kodlu öğretmenin sıra sayısı kavramları için belirttiği "Uygulamalı olarak göstererek, açıklamalar yaparak etkinlik yapıyorum" ifadesi; "Dolaylı Öğretim" kategorisi için Ö3 kodlu öğretmenin dün-bugün-yarın kavramlarına açısından belirttiği "Kelimeleri öncelikle ben sik sik ve tam zamanında kullanıyorum ki çocuklarda kulak aşinalı̆̆ olsun ve onlar da doğru zamanda doğru kelimeyi kullansınlar istiyorum" ifadesi; Müzik Yoluyla Öğretim kategorisi açısından yine Ö1 kodlu öğretmenin içindedışında kavramlarına ilişkin yapılan hataların giderilmesine yönelik ortaya koyduğu "Pepe'nin şarkısını açarım. O zaman çok etkili oluyor" ifadesi; Aile Katılımı Etkinlikleri kategorisi açısından Ö1 kodlu öğretmenin para kavramına ilişkin ortaya koyduğu "Çocuklarl aileleriyle birlikte bakkala, alıs-veriş merkezine gönderiyorum" ifadesi; Analoji kategorisi için Ö5 kodlu öğretmenin kenar ve köşe kavramları açısından belirttiği "iki çocuğun el ele tutuşmasını istiyorum. Kollarını dik bir şekilde açıp el ele tutuştuklarında kollarının kenar, ellerini birleştirdikleri yerlerin ve kafalarının köşeler olduğunu söyleyip kare şeklini bu şekilde ögrretmeye çalışlyorum" ifadesi; Deney kategorisi için Ö10 kodlu öğretmenin derin-sı ̆ kavramları açısından belirttiği "İki tane çukur kazıyorum. Çukurun biri derin biri derin olmuyor. İçlerini su ile dolduruyorum. Çocuklara bu sulardan hangisi derin hangisi sı̆̆ olabilir? Bunu nasll anları?? gibi sorular soruyorum. Sonrasinda çocuklara bir oyuncak bebek veriyorum ve hangi bebeğin suya tamamen battı̆̆ını hangisini beline geldiğini deneyerek öğrenmelerini sağllyorum" ifadesi; Tekrar kategorisi için Ö4 kodlu öğretmenin tam-yarım kavramları açısından belirttiği "Slk pratikler yaptırarak anlık ögrenmelerini yakalamayl deniyorum" ifadesi; Cesaretlendirme kategorisi için Ö4 kodlu öğretmenin tekçift kavramları açısından belirttiği "Çocuğa, bu hatayı yapmanın normal olduğunu ancak kendisinin bu hatayı fark edebilecek ve doğrusunu yapabilecek beceriye sahip olduğunu hatırlatarak tekrar yapmasını bekliyorum" ifadesi ve son olarak Tartışma kategorisi içi Ö5 kodlu öğretmenin dikdörtgen kavramı açısından belirttiği "Çocuklarla kare ve dikdörtgenin benzer özellikleri, farklarl hakkında konuşup, şeklin kare mi yoksa dikdörtgen mi olduğunu nasıl anladıkları konusunda tartışmalarını sağlıyorum" ifadesi örnek gösterilebilir.

\section{Sonuç ve Tartışma}

$\mathrm{Bu}$ araştırmada okul öncesi dönemdeki çocukların matematik kavramlarıyla ilgili yaptıkları hatalar okul öncesi öğretmenlerinin görüşleri açısından incelenmiştir. $\mathrm{Bu}$ bölümde öğretmen görüşleri açısından, okul öncesi dönemdeki çocukların hangi matematiksel kavramlara ilişkin sıklıkla hatalar yaptıkları, hata türünün betimlenmesi, hataların olası nedenleri ve öğretmenlerin bu hataları nasıl giderdiklerine yönelik ortaya çıkan sonuçlar ve tartışmalar ayrı başlıklar altında sunulmuştur.

\subsection{Sıklıkla Hata Yapılan Kavramlara İlişkin Sonuçlar ve Tartışma}

$\mathrm{Bu}$ araştırmanın sonuçlarına göre, öğretmen görüşleri açısından okul öncesi dönemdeki çocuklar şekil kavramları için üçgen kavramı hariç olmak üzere, öğretmenler tarafından dile getirilme sıklığına göre kenar, çember, daire, dikdörtgen, elips, köşe ve kare kavramlarının kazanım süreçlerinde sıklıkla hatalar yapmaktadırlar. Buna karşın Kesicioğlu, Alisinanoğlu ve Tuncer (2011) ise yaptıkları çalışma sonucunda okul öncesi dönemdeki çocukların üçgen kavramına ilişkin kavram yanılgılarının olduğunu ortaya koymuştur.

Boyut kavramlarına ilişkin olarak araştırmanın sonuçları bize, öğretmen görüşleri açısından okul öncesi dönemdeki çocukların, dile getirilme sıklığı açısından sırasıyla genişdar ve ince-kalın kavramlarının kazanım süreçlerinde sıklıkla hatalar yaptıklarını gösterir. Bunun yanında büyükküçük-orta ve uzun-kısa kavramları ise sıklıkla hata yapılan kavramlar arasında yer almamıştır. Bu durumun sebebi olarak boyut kavramlarının sayı olarak az olması ve 
çocukların gelişim-öğrenme özellikleri açısından nispeten kolay kazanılabilen kavramlar olması sebep gösterilebilir.

Miktar kavramlarına ilişkin bu araştırmanın sonuçlarına bakıldığında ise; okul öncesi öğretmenlerinin görüşleri açısından çocukların, dile getirilme sıklığına göre sırasıyla para, tek-çift, kalabalık-tenha, eşit, parça bütün, tam-yarım ve ağır-hafif kavramlarının kazanım süreçlerinde sıklıkla hatalar yaptıkları görülmektedir. Bunun yanında çalışmaya katılan ögrretmenler okul öncesi eğitim programında yer alan az-çok ve boş-dolu kavramlarını çocuklar tarafından kazanım süreçlerinde sıklıkla hata yapılan kavramlar olarak ele almamıştır. Bu durumun sebebi olarak ele alınmayan kavramların günlük yaşamda sıklıkla kullanılan, çocuklar tarafindan aşina olunan ve bu tür nedenlerden dolayı kazanılması diğer kavramlara göre daha kolay olabilen kavramlar olması gösterilebilir.

Araştırmanın Yer-Yön kavramlarına ilişkin sonuçlarına göre ise; öğretmen görüşleri açısından, okul öncesi dönemdeki çocukların, öğretmenler tarafindan dile getirilme sıklığına göre sırasıyla sağ-sol (sağında-solunda), önünde-arkasında, içinde-dışında, arasında, alçak-yüksek ve uzak yakın kavramlarının kazanım süreçlerinde sıklıkla hata yaptıkları ortaya çıkmıştır. Araştırmaya katılan öğretmenler, okul öncesi eğitim programında yer alan yukarı-aşağı, ileri-geri, altında-ortasında-üstünde, yanında ve iç-dış kavramlarına, kazanım süreçlerinde çocuklar tarafindan sıklıkla hata yapılan kavramlar arasında yer vermemiştir. Ortaya çıkan bu sonucun sebebi olarak, öğretmenler tarafından sıklıkla hata yapılan kavramlar olarak ele alınmayan kavramların yön hissi ve uzamsal ilişkiler açısından daha somut ve bu nedenle çocuklar tarafından kazanılması daha kolay kavramlar oluşu gösterilebilir.

Yine bu araştırmanın sayı kavramı ile ilgili sonuçlarında; öğretmen görüşleri açısından, okul öncesi dönemdeki çocukların, dile getirilme sıklığına göre sirasıyla 10-20 arası sayılar, önceki-sonraki, ilk-orta-son, sıra sayısı, sıfır ve 1-10 arası sayı kavramlarının kazanımı süreçlerinde sıklıkla hata yaptıkları görülür. Araştırmaya katılan öğretmenlerden Ö3 kodlu öğretmenin "İşin içine çift basamak girince iyice kafaları karışıyor. Sayıları yanlış okuyorlar. On üç yerine bir üç diyorlar" ifadesi tekrar ele alındığında, bu ifadenin Bryant ve Nunes (2011), Gervasoni (2003) ve Mohyuddin ve Khalil'in (2016) okul öncesi dönem çocukların 2 basamaklı sayılar konusunda basamak değerine dikkate etmedikleri için hata yaptıkları ve bu yüzden yanlış telaffuzlarda bulundukları şeklinde ortaya koydukları bulgularla benzerlik gösterdiği görülür. Olkun, Fidan ve Özer-Babacan (2015) yaptıkları bir çalışmada okul öncesi dönemdeki çocukların sayıları doğru sırada sayabilmelerine rağmen sayılarla ile nesneleri eşleştirmede yani anlamlı saymada zorlandıklarını ifade etmişlerdir. Sayı kavramları açısından dikkate değer bir sonuç olarak ise, okul öncesi eğitim programında sayı kavramları altında yer alan tüm kavramların, öğretmenler tarafından kazanım süreçlerinde sıklıkla hata yapılan kavramlar olarak ele alınışı gösterilebilir. Ortaya çıkan bu sonucun nedenleri olarak sayıların matematiğin ifade dili oluşu ve nispeten soyut oluşu, bu tür nedenlerden dolayı ise çocuklar tarafından kazanılması zor bir kavram oluşu gösterilebilir.
Zit kavramlar açısından sonuçlara bakıldığında; öğretmen görüşleri açısından, okul öncesi dönemdeki çocukların dile getirilme sıklığına göre sirasıyla derin-sığ ve benzer kavramlarının kazanımı süreçlerinde sıklıkla hata yaptıkları görülür. Okul öncesi eğitim programında kazandırılması hedeflenen zıt kavramlardan aynı, farklı, açık-kapalı, hızlıyavaş, ters-düz, başlangıç-bitiş ve düz-eğri kavramlarının ise öğretmenler tarafından, sıklıkla hata yapılan kavramlar arasında ele alınmadığı ortaya çıkmıştır. Bu sonucun ortaya çıkması zıt kavramların kazanımının çocuklar açısından nispeten basit olduğu, genellikle kavram öğretiminin zit kavramların birlikte ele alınması ile gerçekleştirildiği için çocukların zıt kavramları daha iyi kavraması, ilgili zıt kavramların çocuklar için günlük yaşamda diğer kavramlara göre daha somut ve sıklıkla deneyimlenebilen kavramlar olabileceği gibi nedenlerle açıklanabilir. Bu fikirler Ö7 kodlu öğretmenin derin-sı ̆ kavramları için belirttiği "Çocuklar derin-sı̆ kavramlarını somut deneyimleyemiyorlar" ifadesi ile Ö13 kodlu öğretmenin benzer kavramı açısından belirttiği "Nesnelerin benzerliklerini neye göre ayırt edebileceğini tespit etmede sıkıntı yaşıyorlar. Kavramlar arasında ilişki kuramıyorlar. Mesela kitap, kalem, defter ve tencere resmi sunulduğunda hepsinin cansız olduğunu anlayabiliyorlar ama tencere haricindekilerin sınıfta kullanılan araçlar olduğu için benzer yönlerinin olduğunu bu yüzden ilişkili olduğunu anlamıyorlar" ifadesi ile desteklenebilir. Phillips ve Pexman (2015) zıt kavramların çocuklar tarafindan 4-5 yaş civarında kazanıldığı bunun yanında tam olarak anlayış geliştirilemediğini vurgularken Uzun (2013) ise yaptığı çalışmada kendilerine özel bir eğitimsel uygulama sunulan okul öncesi dönemdeki çocukların zıt kavramları kazanmada oldukça başarılı olduklarını ifade etmiştir.

Son olarak zaman kavramları açısından araştırmanın sonuçlarına göre; öğretmen görüşleri açısından çocuklar, dile getirilme sıklığına göre sirasıyla dün-bugün-yarın, sabah-öğle-akşam ve önce-şimdi-sonra kavramlarının kazanımı süreçlerinde sıklıkla hata yaptıkları ortaya çıkmıştır. Bunun yanında okul öncesi eğitim programında zaman kavramları arasında kazandırılmak istenen gecegündüz kavramları ise öğretmenler tarafından, çocukların kazanım süreçlerinde sıklıkla hata yaptıkları kavramlar olarak ele alınmamıştır. Bu sonuçlar zaman kavramının çocuklar açısından soyut kavramlar oluşu, somut ve anlık olarak gözlemlenebilir veya deneyimlenebilir kavramlar olmayışı bunun yanında gece ve gündüz kavramlarının ise diğerlerine göre daha somut bir şekilde gözlemlenebilir bir kavram oluşu ile açıklanabilir. $\mathrm{Bu}$ fikirler Ö8 kodlu öğretmenin dün-bugün-yarın kavramları için belirttiği "Çocuklar yarın kavramını gün içerisinde çok karıştırıyorlar. Yarını, bugün için yaşayamadıkları için onlara soyut kalıyor. Karıştırıyorlar" ifadesi ile desteklenebilir. İlgili literatürde zaman kavramları çocukların en çok zorlandıkları kavram olarak gösterilmektedir (Haciibrahimoğlu, 2014).

\subsection{Hata Türüne İlişkin Sonuçlar ve Tartışma}

Öğretmen görüşleri açısından çocuklar şekil kavramları altında en çok oranda geometrik şekillerin özelliklerine ilişkin kavram karmaşası yaşamaktadırlar. Bu araştırmada da öğretmenlerin öngördüğü gibi Aktaş-Arnas ve Arslan (2010) ile Clements, Swaminathan, Hannibal ve 
Sarama'nın. (1999) çalışmalarında benzer bir şekilde okul öncesi dönem çocukların geometrik şekillerin kenar ve köşe gibi özelliklerini dikkate almadıkları sadece genel görünümlerini dikkate aldıkları ortaya koyulmuştur. Yine bu araştırma ile öğretmenlerin sıklıkla hata yapıldığını belirttiği kavramları destekler nitelikte bazı çalışmalar mevcuttur. Clements ve Sarama'nın (2000) bir çalışmasında okul öncesi dönem çocukların çember ve elips şekillerini birbirine karıştırdıkları, dört kenara ve iki paralel kenara sahip tüm dörtgenlerin çocuklar tarafindan dikdörtgen olarak nitelendirildiği ortaya koyulmuştur. Benzer şekilde ilgili literatürde yer alan birçok çalışmada (Clements, 1999; Clements ve Sarama, 2011; Ginsburg vd. 2005; Kesicioğlu, Alisinanoğlu ve Tuncer, 2011) okul öncesi dönemdeki çocukların geometri ile ilgili kavramları anlamakta zorlandıkları belirtilmiştir. Korkmaz, Karademir ve Korkmaz (2017) yaptıkları bir çalışmada okul öncesi dönemdeki çocukların genel olarak daire ve çemberin kenar ve köşesi olduğuna dair yanlış bir algıya sahip olduklarını ifade etmişlerdir. Araştırmaya katılan Ö5 kodlu öğretmenin ortaya koyduğu "Kare ile dikdörtgeni karıştırlyorlar" ifadesi, Elia ve Gagatsis'in (2003) çalışmalarında ortaya koydukları çocukların kare ve dikdörtgen şekillerinin özelliklerine tam olarak dikkat etmedikleri için bu şekilleri birbirine karıştırdıkları bulgusu ile benzerlik göstermektedir. Bunun yanında araştırmaya katılan okul öncesi öğretmenleri, okul öncesi eğitim programında yer alan üçgen kavramına, çocuklar tarafindan sıklıkla hata yapılan kavramlar arasında yer vermemiştir. Buna karşın Kesicioğlu, Alisinanoğlu ve Tuncer (2011) ise yaptıkları çalışma sonucunda okul öncesi dönemdeki çocukların üçgen kavramıyla ilgili de sıklıkla yanılgılara sahip olduklarını ifade etmişlerdir. Araştırma ile ortaya çıkan sonuçlar ve ilgili literatürde yer alan çalışma birlikte ele alındığında; öğretmenlerin görüşlerinin çocukların gerçekte sahip oldukları matematiksel anlayışları değerlendirme açısından tek başına yeterli ve etkili bir yol olamayabileceği, öğretmenlerin ilgili kavramlar açısından söz konusu deneyimleri yaşamamış olabileceği ve bireysel farklılıklardan kaynaklı olarak bu şekilde sonuçların ortaya çıkmış olabileceği söylenebilir.

Öğretmenler çocukların boyut kavramlarına ilişkin en çok kavram karmaşası yaşadıklarını düşünürken miktar kavramlarına ilişkin olarak da en çok kavram karmaşası yaşadıklarını ve kavram yanılgılarına sahip olduklarını belirtmiştir. Erden, (2006) yaptığı çalışmada, okul öncesi dönemdeki çocukların miktar kavramına ilişkin hatalar yaptıklarını belirtmiştir. Hunting ve Sharpley (1988) ise yaptıkları çalışmada; çocukların bir bütüne ait bir parçanın o bütünün yarımını temsil etmesi için o bütünün iki eş parçaya ayrılması gerektiğini bilmediklerini ifade etmişlerdir. Guerriero ve Cairns (2017) para kavramı ile ilgili olarak 8 yaş öncesi çocukların genellikle paranın değeri, banknot ve bozuk paralar ve değerleri konusunda hatalar yaptıkları ancak 8 yaş sonrasında daha tutarlı bir anlayış geliştirdiklerini ortaya koymuştur.

Yine bu araştırma ile öğretmen görüşleri açısından okul öncesi dönemdeki çocukların çoğunlukla yer-yön kavramlarına ilişkin kavram kargaşası yaşadıkları ortaya koyulmuştur. Buna karşın Lee ve Spelke (2008) okul öncesi dönem çocukların çeşitli referans noktaları aracılığıyla yön bulma ve belirleme konusunda başarılı olduğunu, Tomassi ve Guiliano (2014) ise çocukların yön belirten unsurlardan faydalanarak yön bulma ve belirleme konularında kendilerine has uzamsal stratejiler bile geliştirdiklerini vurgulamıştır. Buna karşın bu araştırmada da ortaya koyulduğu gibi okul öncesi dönem çocukların sağ ve sol kavramlarını birbirine karıștırdıkları, să̆ ve sol kavramlarını anlamlı bir şekilde kullanamadıklarını (Clark ve Klonoff, 1990; Rigal, 1994) vurgulayan çalışmalara rastlanmaktadır. Lee ve Spelke'nin (2008) aksine araştırmaya katılan Ö10 kodlu öğretmenin "Referans noktası problem oluyor. Örneğin masanın sağl senin solun oluyor. Onun için de să̆-sol, să̆ında solunda hep karışıyor" ifadesi bunu destekler niteliktedir.

Öğretmen görüşleri açısından çocukların sayı kavramları açısından en çok kavram karmaşası yaşadıkları ve kavramlar arası ilişki kuramadıkları; zıt kavramlara ilişkin ise en çok ve öncelik sırasına göre kavramları özümseyemedikleri ve kavramları yanlış kullandıkları ortaya çıkmıştır.

Bunun yanında öğretmen görüşleri açısından okul öncesi dönemdeki çocukların zaman kavramlarına ilişkin en çok kavram karmaşası yaşadıkları görülmüştür. HacısalihoğluKaradeniz (2013) de çalışmasında çocukların zaman kavramıyla ilgili kavram kargaşasına sahip oldukları sonucunu ortaya koymuştur. Örnek olarak bu araştırmaya katılan Ö13 kodlu öğretmenin dün-bugün-yarın kavramları açısından belirttiği "Yarın gitmiştik gibi yanlış şeyler söylüyorlar. Zaman kavramlarını yerinde kullanamıyorlar. Kavramları doğru zaman için yerine oturtamıyorlar" ifadesi ile benzer bir şekilde çalıșmalarında bir çocuğun, "Yarın Almanya'dan kuzenim geldi" şeklindeki ifadesi bu çalışmada elde edilen sonuçlarla benzerlik göstermektedir. Araştırmaya katılan Ö3 kodlu öğretmenin belirttiği "Kelime ile zaman arasında ilişki kuramıyorlar" ifadesi, Cockburn'un (2005) araştırmasında zaman kavramının çocuklar tarafından ancak 6-7 yaş civarında gerçek anlamda kazanılmaya başlandığı ve bunun sebebi olarak da zaten soyut ve anlaşılması zor olan zaman kavramlarının bu 6-7 yaş itibariyle yaşamlarında sıkça ve işlevsel olarak kullanılmaya başlanması vurgusuna benzerlik göstermektedir.

\subsection{Hata Nedenlerine İlişkin Sonuçlar ve Tartışma}

$\mathrm{Bu}$ araştırmanın sonucunda, öğretmen görüşleri açısından, okul öncesi dönemdeki çocukların şekil kavramlarına ilişkin kavram kargaşası yaşadıkları, kavram yanılgılarına sahip oldukları ve aşırı genellemeler yaptıkları ortaya koyulmuştur. Öğretmenler yapılan bu hataların çocuklardan, pedagojik etkenlerden ve kavramın doğasından kaynaklanan nedenlerle ortaya çıktığını ifade etmişlerdir. Kesicioğlu, Alisinanoğlu \& Tuncer (2011) de yaptıkları çalışmada, geometrik şekillerin öğretilmesinde kullanılan hatalı yaklaşımların (pedagojik kaynaklı) okul öncesi dönemdeki çocukların şekillerle ilgili hatalar yapmalarına neden olduğunu belirtmişlerdir.

Öğretmenler çocukların miktar kavramına ilişkin yaptıkları hataların ise çoğunlukla çocuklardan ve kavramın doğasından kaynaklanan nedenlerden dolayı ortaya çıktığını belirtmişlerdir. Yer-yön kavramlarına ilişkin hatalarının ise pedagojik etkenlerden, çocuklardan, kavramın doğasından 
ve aileden kaynaklı nedenlerle ortaya çıktı̆̆ı belirtilmiştir. Piaget'in çocuklarda uzay kavramlarının gelişiminde çocukların aktif katılımlar sağlanarak deneyim edinmeleri gerektiğini ifade etmesi pedagojik etkenlerin önemini göstermektedir (Clements, 1999; Kesicioğlu ve Alisinanoğlu, 2014).

Öğretmenler, çocukların sayı kavramlarına ilişkin yaptıkları hataların büyük çoğunluğunun çocuklardan kaynaklanan nedenlerden dolayı ortaya çıktığını ileri sürmüştür. Ayrıca öğretmenler tarafindan çocukların zıt kavramlara ilişkin yaptıkları hataların çocuklardan ve kavramın doğasıdan kaynaklanan nedenlerden dolayı ortaya çıktığı ortaya koyulmuştur. Öğretmen görüşleri açısından çocukların zaman kavramlarına ilişkin yaptıkları hataların çocuklardan kaynaklanan nedenler, pedagojik kaynaklı nedenler ve kavramın doğasından kaynaklanan nedenlerden dolayı ortaya çıktığı görülmüştür.

\subsection{Hataların Giderilmesine Yönelik Stratejilere İlişkin Sonuçlar ve Tartışma}

Araştırmaya katılan öğretmenlerin, okul öncesi dönemdeki çocukların geometrik şekillere ilişkin yaptıkları hataların giderilmesi açısından bir strateji olarak dile getirilme sıklığına göre sırasıyla eğitsel oyun, görselleştirme, sunuş yoluyla öğrenme, somut yaşantı sunma, düz anlatım, buluş yoluyla öğrenme, çalışma yaprağı, sanat etkinliği, tartışma ve analojiyi tercih ettikleri; ögrretmenlerin hata durumlarının çoğunluğu karşısında çocukların gelişimsel özellikleri ve şekil kavramlarının doğası açısından uygun stratejiler uyguladıkları ortaya çıkmıştır.

Öğretmenlerin çocuklar tarafından boyut kavramlarına ilişkin olarak ortaya koyulan hataların giderilmesi açısından eşit oranda eğitsel oyun, sunuş yoluyla öğrenme ve dolaylı öğretimi birer strateji olarak tercih ettikleri; öğretmenlerin boyut kavramlarına ilişkin hata durumları karşısında çocukların gelişimsel özellikleri ve boyut kavramlarının doğası açısından uygun stratejiler kullandıkları ortaya çıkmıştır.

Çalışmaya katılan öğretmenlerin, çocukların miktar kavramına ilişkin yaptıkları hataların giderilmesi açısından dile getirilme sıklığına göre sırasıyla eğitsel oyun, somut yaşantı sunma, eğitici materyal sunma, tekrar, aile katılımı, düz anlatım, buluş yoluyla öğrenme, cesaretlendirme, günlük yaşamdan örnekler sunma, sunuş yoluyla öğrenme, demonstrasyon, çalışma yaprağı ve aktif öğrenmeyi birer strateji olarak kullandıkları ortaya çıkmıştır. Hunting ve Sharpley (1988) bu araştırmada da öğretmenler tarafindan bir strateji olarak kullanıldığı ortaya çıkan günlük yaşamla ilişkilendirmenin çocukların parça-bütün kavramıla ilgili hatalarının giderilmesi açısından önemine vurgu yapmıştır. Sonuç olarak öğretmenlerin miktar kavramına ilişkin hata durumlarının büyük çoğunluğu karşısından çocukların gelişimsel özellikleri ve miktar kavramlarının doğası açısından uygun stratejiler kullandıkları ortaya çıkmıştır.

Yer-yön kavramları açısından araştırmanın sonucunda öğretmenlerin hataların giderilmesinde, dile getirilme sıklığına göre sırasıyla eğitsel oyun, sunuş yoluyla öğrenme, müzik yoluyla öğrenme, sanat etkinlikleri, demonstrasyon, buluş yoluyla öğrenme, drama, somut yaşantı sunma, görselleştirme ve dolaylı öğretimi kullandıkları ortay çıkmıştır. Bunun yanında yalnız bir öğretmenin ise yer-yön kavramlarına ilişkin hataların giderilmesi açısından bir durum karşısında herhangi bir strateji uygulayamadığı görülmüştür. Clements (1999) de okul öncesi denemdeki çocuklarda uzamsal düşünmenin gelişmesi için; iki ve üç boyutlu somut materyaller ile bilgisayar destekli görsel materyallerin ve sanat etkinliklerinin kullanılması gerektiğini belirtmiştir. Sonuç olarak öğretmenlerin yer-yön kavramlarına ilişkin çoğu hata durumları karşısında çocukların gelişim özellikleri ve yer-yön kavramlarının doğası açısından uygun stratejiler kullandıkları ortaya çıkmıştır.

Sayı kavramları açısından öğretmenlerin, hataların giderilmesi açısından dile getirilme sıklığına göre sırasıyla sunuş yoluyla öğrenme, düz anlatım, eğitsel oyun, aktif öğrenme, hikayeleştirme, görselleştirme, buluş yoluyla öğrenme, drama, demonstrasyon, deney ve analojiyi kullandıkları; bunun yanında bir öğretmenin ise herhangi bir strateji uygulayamadığı görülmüştür. Genel olarak çocukların gelişimsel özellikleri ve sayı kavramlarının doğası açısından ise çoğu hata durumu karşısından uygun olmayan stratejiler kullandıkları ortaya çıkmıştır. Akça, Arslan ve Akgül (2013) yaptıkları çalışmada yaratıcı tipografi kartlarının çocuklarda 1'den 10'a kadar olan sayıları daha kalıcı öğrenmelerini sağladığını ifade etmişlerdir. Alptekin (2015) ise yaptığ öğretmenlerin, çocuklarda sayı kavramını kazanmalarını sağlamak ve çocukların hatalarını gidermek için bilimsel araştırmalar sonucunda etkililikleri kanıtlanmış öğretim yöntemlerini (açık anlatım, yanlışsız öğretim, gömülü öğretim gibi) tercih etmeleri gerektiğini ifade etmiştir.

Öğretmenlerin zit kavramlara ilişkin hatalarının giderilmesine yönelik olarak en fazla oranda herhangi bir strateji uygulayamadıkları görülse de dile getirilme sıklığına göre sırasıyla sunuş yoluyla öğrenme, görselleştirme, eğitsel oyun, günlük yaşamdan örnekler sunma, buluş yoluyla öğrenme, çalışma yaprakları, deney, dolaylı ögretim ve somut yaşantı sunmayı bir strateji olarak kullandıkları görülür. Okul öncesi dönemdeki çocukların gelişimsel özellikleri ve zit kavramların doğası düşünüldüğünde hata durumlarının büyük çoğunluğu karşısında uygun stratejiler kullandıkları görülür.

Son olarak öğretmenlerin, zaman kavramlarına ilişkin yapılan hataların giderilmesi amacıyla, dile getirilme sıklığına göre sırasıyla günlük yaşamdan örnekler sunma, sunuş yoluyla öğrenme, hikayeleştirme, görselleştirme, drama, düz anlatım, sanat etkinliği, eğitsel oyun ve dolaylı öğretimi birer strateji olarak kullandıkları görülür. Okul öncesi dönemdeki çocukların gelişimsel özellikleri ve zaman kavramlarının doğası düşünüldüğünde çoğu hata durumu karşısından öğretmenlerin uygun stratejiler kullandıkları ortaya çıkmıştır. Haciibrahimoğlu (2014) okul öncesi dönemdeki çocukların zaman kavramlarıyla ilgili yaşadıkları öğrenme zorluklarının giderilmesinde, zaman kavramlarının günlük etkinliklerde sıkça kullanılarak çocukların deneyim kazanmaları gerektiğini ifade etmiştir. Aktın ve Dilek (2016) ise çocuklara zaman kavramı kazandırılırken; dün, bugün ve yarın kavramlarını içeren basit zamana yönelik yer verilmesi gerektiği ifade edilmiştir. Hacısalihoğlu-Karadeniz (2013) de, çocukların Türkçe, okuma-yazma, müzik, sanat ve drama gibi çeşitli okul öncesi eğitim etkinliği ile "zamanın farkında olma" becerisini geliştirdikleri belirtilmiştir. 


\subsection{Araştırmanın Genel Sonuçları ve Tartışma}

Araştırmanın sonuçlarına genel olarak bakıldığında okul öncesi öğretmenlerinin görüşleri açısından çocuklar birçok matematiksel kavramda çeşitli türlerde hatalar yapmaktadır. Öğretmen görüşleri açısından okul öncesi dönemdeki çocukların en fazla oranda matematiksel kavramlara ilişkin kavram karmaşası yaşadıkları ortaya çıkmıştır. Takiben ve dikkate değer oranlarda ise matematiksel kavramları özümseyemedikleri, matematiksel kavramlar arasında ilişki kuramadıkları, kavram yanılgılarına sahip oldukları ve matematiksel kavramları yanlış kullandıkları ortaya çıkmıştır. Hata yapma oranları açısından sırasıyla şekil kavramları, sayı kavramları, miktar kavramları, zaman kavramları, yer yön kavramları, zıt kavramlar ve boyut kavramları sıralaması ortaya çıkmıştır. Öğretmenler tarafindan çocukların yaptığı hatalara ilişkin çok çeşitli nedenler öne sürülmüştür. Nedenlere ait kategoriler ve parantez içerisinde kategorilerde en sık dile getirilen neden olarak sıralama çocuklardan kaynaklanan nedenler (bilişsel düzey yetersizliği), kavramın doğasından kaynaklanan nedenler (kavramın soyutluğu), eğitimcilerden kaynaklanan nedenler (öğretim ilkelerine uyulmaması), ailelerden kaynaklanan nedenler (kavramın yanlış kullanımı) ve toplumdan kaynaklanan nedenler (kavramın yanlış kullanımı) şeklinde ortaya çıkmıştır. Son olarak öğretmenler matematiksel kavram kategorilerinden yer alan kavramlara ilişkin hataların giderilmesine yönelik olarak en fazla oranda eğitsel oyunu, dile getirilme sıklığına göre takiben sunuş yoluyla öğrenme, görselleştirme, düz anlatım, buluş yoluyla öğrenme, günlük yaşamdan örnekler sunma ve somut yaşantı sunma ve çalışma yaprağını kullandıkları; çocukların gelişimsel özellikleri ve kavramların doğası düşünüldüğünde, şekil kavramları, boyut kavramları, miktar kavramları, yer-yön kavramları, zit kavramlar ve zaman kavramları açısından uygun stratejiler kullandıkları bunun yanında sayı kavramları açısından ise çoğunlukla uygun olmayan stratejiler kullandıkları ortaya çıkmıştır.

\section{5. Öneriler}

Araştırma ile ortaya koyulan sonuçlar doğrultusunda eğitimcilerin eğitimi açısından uygulamaya dönük olarak öğretmen eğitimi süreçlerinde, okul öncesi öğretmen adaylarına senaryo temelli öğretimlerle, çocukların matematikle ilgili deneyimlerini gözlemleme şansı sunularak veya en azından çocukların matematikle ilgili deneyimlerine örnek teşkil eden video-görsel materyallerle desteklenerek erken çocukluk döneminde matematik eğitimine yönelik daha donanımlı olmaları sağlanabilir. Erken çocukluk döneminde matematik eğitimine yönelik daha fazla uygulamalı dersler, çocukların matematik deneyimlerini gözlemleyebilecekleri çeşitli dersler, erken çocukluk döneminde matematik eğitimine yönelik yöntemteknik-stratejilerle ilgili dersler sunulabilir.

Okul öncesi eğitimi öğretmeni olarak görev yapmakta olan öğretmenler açısından uygulamaya dönük olarak, hizmet içi eğitimlerle veya halihazırda görev yapmakta olan öğretmenlere çeşitli imkanlar sunularak çocukların matematiksel kavramları kazanma süreçleri, bu süreçlerde yaptıkları hatalar, hataların giderilmesi ve eğitimsel anlamda olumlu yönde kullanılabilmesi açısından farkındalık oluşturulması ve öğretmenlerin daha donanımlı olması sağlanabilir.
Çocuklara sunulacak imkanlar açısından uygulamaya dönük olarak, matematiksel hataları ortaya çıkarıcı, çocukların kendi hatalarını fark etmelerini sağlayacak düzeyde hata kontrolü gerektiren materyaller gibi çeşitli eğitici materyaller sunularak çocukların matematiksel hatalarının ve yanlış anlayışlarının giderilmesi sağlanabilir.

Araştırmaya dönük olarak ise, çocukların matematiksel hatalarının giderilmesine yönelik geliştirilen uygulamalar ve eğitici araçların etkililiğinin incelenebileceği araştırmalar, çocukların matematiksel kavramlara ilişkin sahip oldukları yanlış anlayışları ortaya çıkarabilecek görev temelli (task) ölçme araçları veya gözlem formlarının geliştirilmesine yönelik araştırmalar planlanabilir.

\section{Kaynakça}

Akça, R. P., Arslan, R. ve Akgül, H. (2013). Okulöncesi eğitiminde çocukların sayıları öğrenmesinde resimli tipografi kartlarının etkisi. Batman Üniversitesi Yaşam Bilimleri Dergisi, 3(1), 13-28.

Akman, B. (2002). Okul öncesi dönemde matematik. Hacettepe Üniversitesi Ĕ̆itim Fakültesi Dergisi, 23, 244-248.

Aktaş-Arnas, Y. ve Aslan, D. (2010). Children's classification of geometric shapes. Çukurova Üniversitesi Sosyal Bilimler Enstitüsü Dergisi, 19(1), 254-270.

Aktın, K. ve Dilek, D. (2016). Okul öncesi dönemde kronolojik düşünme: bir durum çalışması. Sakarya Üniversitesi Eğitim Bilimleri Enstitüsü Dergisi, 6(3), 129-144.

Alptekin, S. (2015). Sayma becerilerinin öğretimi. Ankara Üniversitesi Ĕgitim Bilimleri Fakültesi Özel Ĕ̆itim Dergisi, 16(1), 63-72.

Baysen, E., Güneyli, A. ve Baysen, F. (2012). Kavram öğrenme-öğretme ve kavram yanılgıları: Fen bilgisi ve Türkçe öğretimi örneği. International Journal of New Trends in Arts, Sports \& Science Education, 1(2), 108117.

Bell, A. (1993). Principles for the design of teaching, Educational Studies in Mathematics, 24(1), 5-34.

Bingölbali, E. ve Özmantar, M. F. (2012). Matematiksel kavram yanılgıları: sebepleri ve çözüm arayışları. İçinde Bingölbali, E. ve Özmantar, F. (Ed.), İlköğretimde karşılaşılan matematiksel zorluklar ve çözüm önerileri (3. Bask1). Pegem Akademi, Ankara, Türkiye.

Bishop, A. J., Hart, K., Lerman, S. ve Nunes, T. (1993). Significant influences on children's learning of mathematics. Paris: UNESCO.

Bryant, P. ve Nunes, T. (2011). Childen's understanding of mathematics. İçinde Goswami, U. (Ed.) The Wileyblackwell handbook of childhood cognitive development, (2.Bask1). UK: Blackwell.

Büyüköztürk, Ş., Kılıç-Çakmak, E., Akgün, Ö. E., Karadeniz, Ş. ve Demirel, F. (2011). Bilimsel araştırma yöntemleri. (8.baskı). Ankara: Pegem Yayınları. 
Campbell, L. ve Campbell, B. (2008). Mindful learning: 101 proven strategies for student and teacher success. Corwin Press.

Claessens, A., Duncan, G. ve Engel, M. (2009). Kindergarten skills and fifth-grade achievement: Evidence from the ECLS-K. Economics of Education Review, 28(4), 415-427.

Clark, C. M. ve Klonoff, H. (1990). Right and left orientation in children aged 5 to 13 years. Journal of Clinical and Experimental Neuropsychology, 12(4), 459-466.

Clements, D. H. (1999). Geometric and spatial thinking in young children. In J. V. Copley (Ed.), Mathematics in the early years (pp. 66-79). Reston, VA: National Council of Teachers of Mathematics.

Clements, D. H \& Sarama, J. (2000). Young children's ideas about geometric shapes. Teaching Children Mathematics. 6(8), 482-488.

Clements, D. H., ve Sarama, J. (2011). Early childhood teacher education: The case of geometry. Journal of Mathematics Teacher Education, 14(2), 133-148.

Clements, D. H., Swaminathan, S., Hannibal, M. A. Z. ve Sarama J. (1999). Young children's concepts of shape. Journal for Research in Mathematics Education, 30(2), 192-212.

Cockburn, A. D. (2005). Teaching mathematics with insight: the identification, diagnosis and remediation of young children's mathematical errors. UK: Routledge.

Copley, J. V. (2000). The young child and mathematics. Washington: National Association for the Education of Young Children.

Elia, I. ve Gagatsis, A. (2003). Young children's understanding of geometric shapes: The role of geometric models. European Early Childhood Education Research Journal, 11(2), 43-61.

Erden, M. (2006). Anaokuluna devam eden 5-6 yaş çocuklarının matematiksel becerileri ile görsel algl becerilerinin karşılaştırılması (Yayımlanmamış Yüksek Lisans Tezi). Hacettepe Üniversitesi, Ankara.

Frye, D., Baroody, A. J., Burchinal, M., Carver, S. M., Jordan, N. C. ve McDowell, J. (2013). Teaching Math to young children. Educator's practice guide. What works. Clearinghouse: NCEE.

Gervasoni, A. (2003). Difficulties children face when learning to count. In L. Bragg, C. Campbell, G. Herbert, \& J. Mousley (Eds.), Mathematics education research: Innovation, networking, opportunity. (Proceedings of the 26th annual conference of the Mathematics Education Research Group of Australasia, Geelong, pp. 388-395). Sydney: MERGA.

Ginsburg, A., Cooke, G., Leinwand, S., Noell, J. ve Pollock, E. (2005). Reassessing U.S. international mathematics performance: New findings from the 2003 TIMSS and PISA. Washington, DC: American Institutes for Research.
Guerriero, C. ve Cairns, J. (2017). Children's use and understanding of money: Evidence from Italy (Working Papers). U.K.: THETA.

Haciibrahimoğlu, B. Y. (2014). Ölçme, B. Akman (Ed.) Okul öncesi matematik eğitimi. Ankara: 4.Baskı, Pegem Yayınevi.

Hacısalihoğlu-Karadeniz, M. (2013). Çocukların zamanın farkında olma becerisini kavrayabilme sürecinde okul öncesi eğitim etkinliklerinin etkililiği. Karadeniz Uluslararası Bilimsel Dergi, 1(20), 244-265.

Herholdt, R. ve Sapire, I. (2014). An error analysis in the early grades mathematics - A learning opportunity?. South African Journal of Childhood Education, 4(1), 43-60.

Hunting, R. P. ve Sharpley, C. F. (1988). Fraction knowledge in preschool children. Journal for Research in Mathematics Education, 19(2), 175-180.

Kandır, A. ve Orçan, M. (2010). Okul öncesi dönemde matematik eğitimi. İstanbul: Morpa.

Kesicioğlu, O. S. ve Alisinanoğlu, F. (2014). Okul öncesi dönemde uzay, geometri ve geometrik şekiller, B. Akman (Ed.) Okulöncesi matematik eğitimi. Ankara: 4.Bask1, Pegem Yayınevi.

Kesicioğlu, O. S., Alisinanoğlu, F. ve Tuncer, A. T. (2011). Okul öncesi dönem çocukların geometrik şekilleri tanıma düzeylerinin incelenmesi. Ilköğretim Online, 10(2), 1093-1111.

Korkmaz, H. İ., Karademir, A. ve Korkmaz, A. (2017). Preschool age children's strategies of recognizing two dimensioned shapes. 15th International Geometry Symposium, 3-6 Temmuz, Amasya, Türkiye.

Lee, S. A. ve Spelke, E. S. (2008). Children's use of geometry for reorientation. Developmental Science. 11(5), 743-749.

Mcmillian, H. J. ve Schumacher, S. (2010). Research in education. Boston, USA: Pearson Education.

MEB (Milli Eğitim Bakanlı̆̆ı) (2013). Milli Eğitim Bakanlığl Ilkögretim Genel Müdürlüğü, 36-72 aylık çocuklar için okul öncesi eğitim program. Ankara: Milli Eğitim Bakanlığg1.

Mohyuddin, R. G. ve Khalil, U. (2016). Misconceptions of students in learning mathematics at primary level. Bulletin of Education and Research, 38(1), 133162.

NCCA (National Council for Curriculum and Assessment) (2014). Mathematics in early childhood and primary education (3-8 years) teaching and learning. Research Report No. 18.

NCTM (National Council of Teachers of Mathematics) (2006). Curriculum focal points for prekindergarten through grade 8 mathematics: A quest for coherence. Reston: National Council of Teaching Mathematics.

Nguyen, T., Watts, T. W., Duncan, G. J., Clements, D. H., Sarama, J. S., Wolfe, C. ve Spitler, M. E. (2016). Which preschool mathematics competencies are most 
predictive of fifth grade achievement? Early Childhood Research Quarterly, 36, 550-560.

Nunes, T. ve Bryant, P. (1997). Learning and teaching mathematics: An international perspective. East sussex: Psychology Pres.

Olkun, S., Fidan, E., ve Özer-Babacan, A. (2013). 5-7 yaş aralığındaki çocuklarda sayı kavramının gelişimi ve saymanın problem çözmede kullanımı. Eğitim ve Bilim, 38(169), 236-248.

OME (Ontario Ministry of Education) (2007). Helping your child do mathematics: A guide for parents. kindegarten to grade 6. Toronto: OME.

Phillips, C. I. ve Pexman, P. M. (2015). When do children understand "opposite"? Journal of Speech, Language, and Hearing Research, 58(4), 1233-1244.

Rigal, R. (1994). Right-left orientation: Development of correct use of right and left terms. Perceptual and Motor Skills, 79(3), 1259-1278.

Ryan, J. ve Williams, J. (2007). Children's mathematics 415: Learning from errors and misconceptions: learning from errors and misconceptions. Berkshire: McGrawHill Education.

Sarama, J. ve Clements, D. H. (2009). Early childhood mathematics education research: Learning trajectories for young children. New York: Routledge.

Sperry-Smith, S. (2006). Early childhood mathematics. (3rd Edition). Boston: Pearson.

Taylor, H. (2013). How Children Learn Mathematics and the Implications for Teaching İçinde Taylor, H. ve
Harris, A (Ed.) Learning and teaching mathematics 0-8. SAGE.

Tommasi, L. ve Guiliano, A. (2014). Evidence of a relational spatial strategy in learning the centre ofenclosures in human children (homo sapiens). Behavioral Processes. 106, 172-179.

Türkdoğan, A., Güler, M., Bülbül, B. Ö. ve Danişman, Ş. (2015). Türkiye'de matematik eğitiminde kavram yanılgılarıyla ilgili çalışmalar: Tematik bir inceleme. Mersin Üniversitesi Ĕ̈itim fakültesi Dergisi, 11(2), 215-236.

Türkdoğan, A. (2014). Nicel, nitel ve karma araştırma. İçinde Demir, S. B. (Çev. Edt.). Eğitim Araştırmaları, 29-56.

Uzun, A. (2013). Aile katılımı odaklı matematik destek programının okul öncesi eğitim kurumuna devam eden 60-72 aylık çocukların matematiksel kavram edinimine etkisinin incelenmesi (Yayımlanmamış Yüksek Lisans Tezi). Çanakkale 18 Mart Üniversitesi, Çanakkale.

Watts, T. W., Duncan, G. J., Siegler, R. S. ve Davis-Kean, P. E. (2014). What's past is prologue: Relations between early mathematics knowledge and high school achievement. Educational Researcher, 43(7), 352-360.

Yenilmez, K. ve Yaşa, E. (2008). İlköğretim öğrencilerinin geometrideki kavram yanılg1ları. Uluda $\breve{g}$ Üniversitesi Eğitim Fakültesi Dergisi, 21(2), 461-483.

Yıldırım, A. ve Şimşek, H. (2011). Sosyal bilimlerde nitel araştırma yöntemleri (8.baskı). Ankara: Seçkin Yayınc1lık. 


\section{EK1: Okul Öncesi Dönemdeki Çocukların Matematiksel Kavramlara İliş̧in Genel Hataları}

\section{Sevgili Öğretmenler}

Bu form, okul öncesi dönemdeki çocuklarının kavram kazanımı sürecinde sıklıkla hata yaptıkları matematiksel kavramların ortaya çıkarılması amacıyla geliştirilmiştir. Size göre okul öncesi dönemdeki çocukların, aşağıda listelenen kavramlarla ilgili hata yapma sıklıklarını, her bir kavram için; "Hiçbir Zaman”, "Çok Nadir”, "Bazen”, "Çoğunlukla” veya "Her Zaman” seçeneklerinden yalnızca birini işaretleyerek belirtiniz.

\begin{tabular}{|c|c|c|c|c|c|c|}
\hline \multicolumn{2}{|l|}{ KAVRAMLAR } & 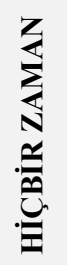 & 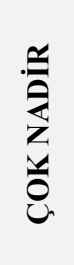 & 茎 & 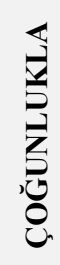 & 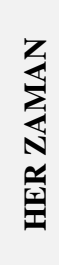 \\
\hline \multirow{8}{*}{ ŞEKILL KAVRAMLARI } & Daire & $\square$ & $\square$ & $\square$ & $\square$ & $\square$ \\
\hline & Çember & $\square$ & $\square$ & $\square$ & $\square$ & $\square$ \\
\hline & Üçgen & $\square$ & $\square$ & $\square$ & $\square$ & $\square$ \\
\hline & Kare & $\square$ & $\square$ & $\square$ & $\square$ & $\square$ \\
\hline & Dikdörtgen & $\square$ & $\square$ & $\square$ & $\square$ & $\square$ \\
\hline & Elips & $\square$ & $\square$ & $\square$ & $\square$ & $\square$ \\
\hline & Kenar & $\square$ & $\square$ & $\square$ & $\square$ & $\square$ \\
\hline & Köşe & $\square$ & $\square$ & $\square$ & $\square$ & $\square$ \\
\hline \multirow{6}{*}{ BOYUT KAVRAMLARI } & Büyük & $\square$ & $\square$ & $\square$ & $\square$ & $\square$ \\
\hline & Küçük & $\square$ & $\square$ & $\square$ & $\square$ & $\square$ \\
\hline & Orta & $\square$ & $\square$ & $\square$ & $\square$ & $\square$ \\
\hline & İnce-Kalın & $\square$ & $\square$ & $\square$ & $\square$ & $\square$ \\
\hline & Uzun-Kısa & $\square$ & $\square$ & $\square$ & $\square$ & $\square$ \\
\hline & Geniş-Dar & $\square$ & $\square$ & $\square$ & $\square$ & $\square$ \\
\hline \multirow{9}{*}{$\begin{array}{l}\text { MIKTAR } \\
\text { KAVRAMLARI }\end{array}$} & Az-Çok & $\square$ & $\square$ & $\square$ & $\square$ & $\square$ \\
\hline & Ağır-Hafif & $\square$ & $\square$ & $\square$ & $\square$ & $\square$ \\
\hline & Boş-Dolu & $\square$ & $\square$ & $\square$ & $\square$ & $\square$ \\
\hline & Tek-Çift & $\square$ & $\square$ & $\square$ & $\square$ & $\square$ \\
\hline & Yarım-Tam & $\square$ & $\square$ & $\square$ & $\square$ & $\square$ \\
\hline & Eşit & $\square$ & $\square$ & $\square$ & $\square$ & $\square$ \\
\hline & Kalabalık-Tenha & $\square$ & $\square$ & $\square$ & $\square$ & $\square$ \\
\hline & Parça-Bütün & $\square$ & $\square$ & $\square$ & $\square$ & $\square$ \\
\hline & Para & $\square$ & $\square$ & $\square$ & $\square$ & $\square$ \\
\hline \multirow{8}{*}{$\begin{array}{l}\text { YER / YÖN } \\
\text { KAVRAMLARI }\end{array}$} & Ön-Arka & $\square$ & $\square$ & $\square$ & $\square$ & $\square$ \\
\hline & Yukarı-Aşağı & $\square$ & $\square$ & $\square$ & $\square$ & $\square$ \\
\hline & İleri-Geri & $\square$ & $\square$ & $\square$ & $\square$ & $\square$ \\
\hline & Sağ-Sol & $\square$ & $\square$ & $\square$ & $\square$ & $\square$ \\
\hline & Önünde-Arkasında & $\square$ & $\square$ & $\square$ & $\square$ & $\square$ \\
\hline & Alt-Üst-Orta & $\square$ & $\square$ & $\square$ & $\square$ & $\square$ \\
\hline & Arasında & $\square$ & $\square$ & $\square$ & $\square$ & $\square$ \\
\hline & Yanında & $\square$ & $\square$ & $\square$ & $\square$ & $\square$ \\
\hline
\end{tabular}


KAVRAMLAR
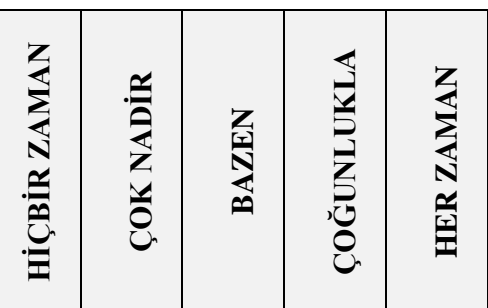

\begin{tabular}{|c|c|c|c|c|c|c|}
\hline \multirow{7}{*}{$\begin{array}{l}\text { YER / YÖN } \\
\text { KAVRAMLARI }\end{array}$} & Yukarıda-Aşağıda & $\square$ & $\square$ & $\square$ & $\square$ & $\square$ \\
\hline & İç-Dış & $\square$ & $\square$ & $\square$ & $\square$ & $\square$ \\
\hline & İçinde-Dışında & $\square$ & $\square$ & $\square$ & $\square$ & $\square$ \\
\hline & İçeri-Dışarı & $\square$ & $\square$ & $\square$ & $\square$ & $\square$ \\
\hline & Uzak-Yakın & $\square$ & $\square$ & $\square$ & $\square$ & $\square$ \\
\hline & Yüksek & $\square$ & $\square$ & $\square$ & $\square$ & $\square$ \\
\hline & Sağında-Solunda & $\square$ & $\square$ & $\square$ & $\square$ & $\square$ \\
\hline
\end{tabular}

\begin{tabular}{|c|c|c|c|c|c|c|}
\hline \multirow{8}{*}{ SAYI KAVRAMLARI } & 1-10 Arası Sayılar & $\square$ & $\square$ & $\square$ & $\square$ & $\square$ \\
\hline & 10-20 Arası Sayılar & $\square$ & $\square$ & $\square$ & $\square$ & $\square$ \\
\hline & Sifir & $\square$ & $\square$ & $\square$ & $\square$ & $\square$ \\
\hline & İlk & $\square$ & $\square$ & $\square$ & $\square$ & $\square$ \\
\hline & Orta & $\square$ & $\square$ & $\square$ & $\square$ & $\square$ \\
\hline & Son & $\square$ & $\square$ & $\square$ & $\square$ & 口 \\
\hline & Önceki-Sonraki & $\square$ & $\square$ & $\square$ & $\square$ & $\square$ \\
\hline & Sıra Savısı (Birinci, ikinci ...) & $\square$ & $\square$ & $\square$ & $\square$ & $\square$ \\
\hline
\end{tabular}

\begin{tabular}{|c|c|c|c|c|c|c|}
\hline \multirow{9}{*}{ ZIT KAVRAMLAR } & Aynı & $\square$ & $\square$ & $\square$ & $\square$ & $\square$ \\
\hline & Farklı & $\square$ & $\square$ & $\square$ & $\square$ & $\square$ \\
\hline & Benzer & $\square$ & $\square$ & $\square$ & $\square$ & $\square$ \\
\hline & Açık-Kapalı & $\square$ & $\square$ & $\square$ & $\square$ & $\square$ \\
\hline & Hızlı-Yavaş & $\square$ & $\square$ & $\square$ & $\square$ & $\square$ \\
\hline & Ters-Düz & $\square$ & $\square$ & $\square$ & $\square$ & $\square$ \\
\hline & Başlangıç-Bitiş & $\square$ & $\square$ & $\square$ & $\square$ & $\square$ \\
\hline & Düz-Eğri & $\square$ & $\square$ & $\square$ & $\square$ & $\square$ \\
\hline & Derin-Sı̆̆ & $\square$ & $\square$ & $\square$ & $\square$ & $\square$ \\
\hline
\end{tabular}

\begin{tabular}{|l|l|c|c|c|c|c|}
\hline \multirow{5}{*}{ ZAMAN KAVRAMLARI } & Önce & $\square$ & $\square$ & $\square$ & $\square$ & $\square$ \\
\cline { 2 - 7 } & Simdi & $\square$ & $\square$ & $\square$ & $\square$ & $\square$ \\
\cline { 2 - 7 } & Sonra & $\square$ & $\square$ & $\square$ & $\square$ & $\square$ \\
\cline { 2 - 7 } & Sabah-Öğle-Akşam & $\square$ & $\square$ & $\square$ & $\square$ & $\square$ \\
\cline { 2 - 7 } & Dün & $\square$ & $\square$ & $\square$ & $\square$ & $\square$ \\
\cline { 2 - 7 } & Bugün & $\square$ & $\square$ & $\square$ & $\square$ & $\square$ \\
\cline { 2 - 7 } & Yarın & $\square$ & $\square$ & $\square$ & $\square$ & $\square$ \\
\hline & Gece-Gündüz & $\square$ & $\square$ & $\square$ & $\square$ & $\square$ \\
\hline
\end{tabular}

